Review

\title{
Early State Research on Antifungal Natural Products
}

\author{
Melyssa Negri, Tânia P. Salci, Cristiane S. Shinobu-Mesquita, Isis R. G. Capoci, \\ Terezinha I. E. Svidzinski and Erika Seki Kioshima *
}

Universidade Estadual de Maringá, Micologia Médica, Av. Colombo, 5790, CEP 87020-900, Brazil; E-Mails: melyssanegri@gmail.com (M.N.); taniasalci@gmail.com (T.P.S.); cristianeshinobu@gmail.com (C.S.S.-M.); isiscapoci@hotmail.com (I.R.G.C.); tiesvidzinski@uem.br (T.I.E.S.)

* Author to whom correspondence should be addressed; E-Mail: eskcotica@uem.br; Tel.: +55-044-3011-4810; Fax: +55-044-3011-4860.

Received: 2 December 2013; in revised form: 1 January 2014 / Accepted: 9 January 2014 / Published: 7 March 2014

\begin{abstract}
Nosocomial infections caused by fungi have increased greatly in recent years, mainly due to the rising number of immunocompromised patients. However, the available antifungal therapeutic arsenal is limited, and the development of new drugs has been slow. Therefore, the search for alternative drugs with low resistance rates and fewer side effects remains a major challenge. Plants produce a variety of medicinal components that can inhibit pathogen growth. Studies of plant species have been conducted to evaluate the characteristics of natural drug products, including their sustainability, affordability, and antimicrobial activity. A considerable number of studies of medicinal plants and alternative compounds, such as secondary metabolites, phenolic compounds, essential oils and extracts, have been performed. Thus, this review discusses the history of the antifungal arsenal, surveys natural products with potential antifungal activity, discusses strategies to develop derivatives of natural products, and presents perspectives on the development of novel antifungal drug candidates.
\end{abstract}

Keywords: antifungal; natural products; essential oils; extracts; fungi 


\section{Introduction}

Fungal participation in the aetiology of infections has increased considerably [1,2]. However, as medical technology has improved, the survival of patients with severe and life-threatening illnesses has led to a rapid increase in the immunosuppressed population [3]. These changes are correlated with a substantial increase in the rate of invasive fungal infections (IFIs). Moreover, drug-resistant strains are emerging, and the number of infections by intrinsically drug-resistant species has increased rapidly [4]. Despite the constant introduction of new and effective synthetic drugs to the market, medicinal plants, which are the historical basis of therapeutic health care, represent an alternative that is economical, accessible, and applicable to various pathologies, particularly in developing countries [5].

Therefore, parallel to the development of synthetic drugs, substantial attention has focused on natural products with antifungal properties, which has stimulated the search for therapeutic alternatives [6,7]. Therapies commonly called alternative, complementary and homemade have been used for centuries, and studies have intensively investigated plant species with medicinal properties to assess the feasibility, sustainability and affordability of the use of natural drugs $[8,9]$.

Plants produce a variety of medicinal components that can inhibit the growth of pathogens, and a considerable number of studies have been conducted to evaluate the antimicrobial activity of extracts and essential oils of medicinal plants [10,11]. Natural products have diverse chemical characteristics that can influence the evaluation of antifungal activity, such as the release of active constituents, solubility, stability, absorption and dissolution. Thus, the focus of this review was to briefly discuss the history of the antifungal arsenal, survey natural products with potential antifungal activity, discuss strategies to develop natural product derivatives, and present perspectives on the development of novel antifungal and novel drug targets.

\section{A Brief History of Antifungal Agents}

In the first decades of the 20th century, there was great concern regarding dermatophytoses and thrush. Consequently, therapeutic attempts were directed toward the treatment of these infections. In 1935, Wieder [12] recognised that the number of fungal dermatoses was growing, necessitating treatment with drugs specific for fungal dermatitis. Since that time, the interest in antifungal clinical therapy has gradually increased. Therapies have been limited to non-specific remedies such as iodide; mercury; benzoic and salicylic acids; phenol derivatives; undecylenic acid; methyl violet; sulphonamide derivatives; and other noxious agents, including bromine, potassium permanganate and oil of turpentine with olive oil [13-15].

Griseofulvin, a compound derived from Penicillium griseofulvum, was the earliest chemical claimed to show selective inhibitory activity against fungi and was widely used to treat superficial fungal infections $[16,17]$. Nystatin, initially called fungicin, was the first polyenic compound with known antifungal activity [18]. Other studies were performed by the same researchers to prove its antifungal efficacy and utility $[19,20]$.

In 1955, an important advance was amphotericin B, which is considered the most effective antifungal drug, even with the adverse side effects such as severe dose-dependent toxicity, including renal impairment and hypokalaemia [21]. Currently, lipid-based formulations of amphotericin B show 
a broad spectrum of activity against pathogenic fungi, with a significantly higher success rate and a lower incidence of nephrotoxicity. However, an important disadvantage associated with lipid formulations is their increased cost [22].

Flucytosine (5-fluorocytosine), a halogenated pyrimidine, was reported as an antifungal in 1961 [23] and was later described as a promising agent against systemic mycoses due to Cryptococcus neoformans and Candida albicans. However, today its use has been restricted as an adjunct medication for the treatment of cryptococcosis in certain countries [24].

The discovery of the azole antifungal drugs, compounds with the generic suffix "conazoles", was a significant accomplishment in the history of antifungal drug development [25]. Ketoconazole, a miconazole derivative, was introduced in 1981 and represents an advance in the search for new safe and effective agents for the treatment of systemic fungal infections as an oral agent. In a screening program, more than 100 triazoles derived from 2,4-dichlorophenyl were tested in mouse models of dermatophytosis and vaginal candidiasis, but only a few drugs entered the market [25].

Fluconazole, a triazole first described in 1985 by Richardson et al. as the main representative of azoles, became the most prescribed antifungal just a few years after being first used clinically; this drug is prescribed for almost all intensive care unit (ICU) patients with antifungal infections [26,27]. In that same decade, itraconazole was shown to be effective against Aspergillus spp. and agents of systemic mycosis such as paracoccidioidomycosis. This drug also has a high affinity for keratinous tissues, so it has been indicated for the treatment of onychomycosis and dermatophytosis [6].

A substantial increase in the number of antifungal drugs occurred at the beginning of this century with the availability of new azoles and echinocandins. Voriconazole was the main primary azole compound introduced as a drug and was approved for first-line treatment of invasive aspergillosis and also showed activity against Fusarium and Scedosporium infections, which are difficult to treat. Others new antifungals included triazoles, ravuconazoles and posaconazoles, although their discovery has not resulted in significant therapeutic gains $[6,22]$. Structurally, voriconazole and ravuconazole are related to fluconazole, whereas posaconazole closely resembles itraconazole [28].

In the early 2000s, the following three echinocandins entered the market: caspofungin, anidulafungin and micafungin. These drugs, which are natural products, are safe and well tolerated, and have minimal drug interactions and favourable pharmacokinetics [29-31]. Current guidelines recommend their use as first-line therapy for candidaemia/invasive candidiasis and as second-line drugs for aspergillosis because of their high activity against fluconazole-resistant Candida spp. and filamentous fungi [32].

Sordarins are a class of semi-synthetic natural products that are potent and selective inhibitors of fungal protein synthesis. A number of molecules based on the sordarin pharmacophore have demonstrated therapeutic efficacy in various animal models of fungal disease but are not yet available for clinical use [33-38].

Another promising new drug is E1210, which is an antifungal with a novel mechanism of action, the inhibition of fungal glycosylphosphatidylinositol biosynthesis. It has suitable in vitro activity against Candida spp. (including fluconazole-resistant strains), C. neoformans, and Aspergillus spp. and a wide range of medically relevant yeast and moulds [39-42].

Others promising drugs have not been used, and others were used but then fell into disuse due to toxicity, cost, spectrum of action, or unfavourable pharmacokinetics [43]. For every 5,000 to 
10,000 experimental compounds tested, it is estimated that only one will obtain Food and Drug Administration (FDA) approval, which usually occurs after 10 to 15 years of research and development [44]. Therefore, extensive research is necessary and essential for the development of new antifungals that could support the combat antifungal resistance and have lower toxicity than current therapies. In addition, the development of new antifungals will allow elucidation of the underlying mechanisms and activity of the drugs to improve their use in medical mycology.

\section{Natural Derivatives with Antifungal Properties}

In addition to the development of synthetic antifungals, alternatives based on natural compounds, such as phenolic compounds, essential oils, and extracts from natural products, have been proposed. Furthermore, recent advances in structural biology, medicinal chemistry, and in silico technologies have allowed the development of promising research, including proposed antifungals based on targets unique to fungi to increase the specificity and reduce side effects [11,45-50].

When determining whether a natural product is an antifungal agent, it is important to consider the following microbiological parameters: (1) the use of a solvent without antifungal activity for compounds with poor solubility; (2) the best method selection, such as microdilution or macrodilution or broth or agar diffusion, according to Clinical and Laboratory Standards Institute Standards (CLSI) document M27-A3, M38-A and M2-A8; (3) careful observation of the rules for a standardised inoculum; (4) the use of reference strains according to the CLSI and pathogenic human fungi; (5) the use of a synthetic drug as the control; and (6) the appropriate incubation time.

Thus, the next section will discuss preliminary research showing promising results for natural products with the potential to be novel antifungal drugs.

\subsection{Extracts}

Plant extract is a generic term for natural product derivatives with chemical components that have not been completely elucidated. Before performing research on the purification of extract components, it is important to screen the extracts for antifungal activity.

Many types of extracts have been reported to show antifungal activity in the literature. Extracts derived from Curcuma zedoaria [51], Psidium guajava [52], Plectranthus amboinicus, Aristolochia cymbifera, Plectranthus barbatus, Lippia alba, Hydrocotyle bonariensis, Hydrocotyle bonariensis, Justicia pectoralis var. stenophylla, Herreria salsaparilha, Mentha X piperita, Eleutherine bulbosa, Baccharis trimera, Calamintha adscendens, Albizia inundata, Bauhinia forficata, Cymbopogon citratus, Plectranthus grandis [53] and Euphorbia hirta L. [54] have all demonstrated activity against Candida spp. More specifically, a study conducted by our group evaluated the antifungal activity of a hydroalcoholic extract of Cymbopogon nardus [49] in comparison with nystatin and fluconazole, and its impact on Candida virulence factors was evaluated. This extract was effective against Candida based on significant changes in the virulence factors, indicating a possible mechanism of action. In addition, a similar study conducted by Polaquini et al. [55] on a crude extract of Neem (Azadirachta indica), and the Candida virulence factors showed a decrease in yeast adhesion capacity, although this extract was not efficient in inhibiting the growth of Candida biofilm. 
Another study of 46 Eurasian area derivatives and extracts from 25 plants belonging to the Asteraceae, Euphorbiaceae, Rubiaceae and Solanaceae botanical families [56] found good activity against filamentous fungi [57]. Crossandra infundibuliformis [58] and Labisia pumila Benth [59] are examples of extracts that showed both Candida spp. and filamentous antifungal activity. Extracts of Tanzanian-derived plants [60], Alpinia galanga and Boesenbergia pandurata were tested for activity against Cryptococcus, a fungi that is difficult to treat [61]. The extracts showed positive results, and these extracts also demonstrated activity against other fungi tested.

The biological activity of an extract may not be experimentally reproducible because the chemical constituents present in the crude extracts may be different. Furthermore, the solvent used to obtain the extract and the extraction method may result in the loss of some compounds. Some studies have shown changes in the chemical composition during different growth stages of plants, and others have shown diversity based on the geographic area of origin [62-64]. Although screening plant extracts can streamline the discovery process, studies have been focused on the elucidation of chemical compounds. Research on crude extracts may be the first step to discovering a new promising compound, which is followed by identification of the chemical compounds responsible for the antifungal activity.

\subsection{Essential Oils}

Essential oils are mixtures of volatile elements contained in diverse plant parts (flowers, leaves, bark, fruits and rhizomes). In most cases, these oils are obtained by steam distillation or by pressing the pericarp of citrus fruits. Essential oils are mainly composed of mono- and sesquiterpenes and phenylpropanoids (Section 3.2.1 Terpenes and Terpenoids), which confer its organoleptic characteristics, are connected with the various functions necessary for plant survival and play a key role in the defence of the plant against microorganisms [65-68].

The antimicrobial action of the different types of essential oils against microorganisms has been studied since the 1950s [69-73]. Viollon and Chaumont [74], using C. neoformans from an HIV-positive patient's blood, evaluated the activity of some-essentials oils and the pure constituents derived from them. Essentials oils from cinnamon, geranium "Bourbon", geranium "Palmarosa", savoury, and thyme showed good fungistatic action, but in general, the pure components (terpenoids, citral, geraniol, and citronellol) showed better activity than the essential oils.

Ocimum gratissimum is popularly used to treat many diseases. Eugenol is the main constituent of this essential oil and is considered to be responsible for its antimicrobial activity [75,76]. According to the in vitro minimum inhibitory concentration (MIC) values and time-kill curves demonstrated by Nakamura et al. [11], the Ocimum gratissimum essential oil had fungicidal activity against all Candida species; $C$. parapsilosis was the most susceptible and C. tropicalis was the least.

Other essential oils have been investigated. De Oliveira Lima et al. [77] evaluated the antifungal activity of Cinnamomum zeylanicum Blume, Citrus limon Risso, Eucalyptus citriodora HK., Eugenia uniflora L., Peumus boldus Benth. and Rosmarinus officinalis L. against Candida. They observed that all of these essential oils were effective in inhibiting at least one tested fungal strain. More specifically, C. zeylanicum and P. boldus showed the best results; they inhibited the growth of $58 \%$ of the tested strains. E. uniflora also showed low level inhibition against Candida strains. 
Essential oils obtained from Achillea millefolium and Curcuma longa demonstrated substantial inhibition of the tested samples (C. albicans, C. glabrata, and C. tropicalis), at $63.2 \%$ and $68.4 \%$, respectively [78]. The essential oil of Nandina domestica Thunb., which contains 1-indolizinecarbazole, 2-pentanone, monophenol, aziridine, methylcarbinol, ethanone, furfural, 1-hydroxy-4-methylbenzene, 2(5H)-furanone, and 3,5-dimethylpyrazole as major components (Table 1), exhibited high antifungal activity in vitro and had a strong detrimental effect on spore germination against Microsporum canis, Trichophyton rubrum and T. mentagrophytes [79].

Recent studies continue to demonstrate the antifungal activity of essential oils [80-83] and consequently increase the possibility of applying these products to the prevention and/or treatment of fungal infectious diseases. The biological activity of essential oils has been shown to be dependent on their chemical compositions, which include citral, pinene, cineole, caryophyllene, elemene, furanodiene, limonene eugenol, eucalyptol and carvacrol. These constituents are known to have antifungal activity, among other properties [84].

There are some clinical studies of essential oils. One example is the research conducted by Carmo et al. [81], which tested the essential oil of Cymbopogon citratus in shampoo and cream formulations to treat pityriasis versicolor. They proved that the formulations, which did not cause significant adverse reactions in healthy volunteers, were safe, and after treatment, a $60 \%$ mycological cure rate was observed for the group treated with this essential oil.

Table 1. Some essential oils, their main constituents and the fungus tested.

\begin{tabular}{|c|c|c|c|}
\hline Essential oil & Main constituents & Fungus tested & Reference \\
\hline Calea clematidea & Clemateol & $\begin{array}{c}\text { Trichophyton rubrum, } \\
\text { T. tonsurans, T. mentagrophytes, } \\
\text { Microsporum gypseum, } \\
\text { M. canis, M. nanum, } \\
\text { Epidermophyton floccosum }\end{array}$ & {$[85]$} \\
\hline Ocimum gratissimum & Eugenol & $\begin{array}{c}\text { C. albicans, } C . \text { krusei, } \\
\text { C. parapsilosis, C. tropicalis }\end{array}$ & {$[11]$} \\
\hline Salvia officinalis & Camphor and cis-thujone & $\begin{array}{l}\text { C. albicans, C. krusei, C. tropicalis, } \\
\text { C. parapsilosis, C. glabrata, E. } \\
\text { floccosum, T. rubrum, T. } \\
\text { mentagrophytes, M. canis, } M . \\
\text { gypseum, A. flavus, Fusarium } \\
\text { moniliforme, Penicillium italicum, } \\
\text { Cladosporium cladosporioides. }\end{array}$ & {$[86]$} \\
\hline $\begin{array}{c}\text { Calendula officinalis } \\
\text { L. }\end{array}$ & $\begin{array}{c}\delta \text {-Cadinene, } \alpha \text {-cadinol and epi- } \alpha \text { - } \\
\text { muurolol }\end{array}$ & $\begin{array}{l}\text { C. albicans, C. dubliniensis, } \\
\text { C. parapsilosis, C. glabrata, } \\
\text { C. tropicalis, C. guilliermondii, } \\
\text { C. krusei, Rhodotorulla sp. }\end{array}$ & {$[87]$} \\
\hline $\begin{array}{l}\text { Nandina domestica } \\
\text { Thunb. }\end{array}$ & $\begin{array}{l}\text { 1-Indolizinocarbazole, 2-pentanone, } \\
\text { monophenol, azridine, } \\
\text { methylcarbinol, ethanone, furfural, } 1 \text { - } \\
\text { hydroxy-4-methylbenzene, } 2(5 \mathrm{H}) \text { - } \\
\text { furanone, and 3,5-dimethyl-pyrazole }\end{array}$ & $\begin{array}{c}\text { T. rubrum, T. mentagrophytes, } \\
\text { M. canis }\end{array}$ & [79] \\
\hline
\end{tabular}


Table 1. Cont.

\begin{tabular}{|c|c|c|c|}
\hline Essential oil & Main constituents & Fungus tested & Reference \\
\hline Piper ovatum Vahl & $\begin{array}{c}\delta \text {-Amorphene, cis-muurola-4(14),5- } \\
\text { diene and } \gamma \text {-muurolene }\end{array}$ & C. tropicalis & {$[88]$} \\
\hline Piper amalago & $\begin{array}{l}\beta \text {-Copaen-4- } \alpha \text {-ol, 7-epi- } \alpha \text {-eudesmol, } \\
\text { epi- } \alpha \text {-cadinol and } n \text {-hexyl benzoate }\end{array}$ & $\begin{array}{c}\text { C. albicans, C. tropicalis, } \\
\text { C. parapsilosis } \\
\end{array}$ & [89] \\
\hline $\begin{array}{l}\text { Achillea } \\
\text { millefolium }\end{array}$ & $\begin{array}{l}\text { Azulene, chamazulene, pinene, } \\
\text { cineole, camphor, } \alpha \text {-bisabolol, } \\
\text { monoterpenes, eucalyptol, borneol, } \\
\text { terpene derivatives, sesquiterpenes, } \\
\text { tannins, mucilage, coumarins, resins, } \\
\text { saponins, steroids, fatty acids, } \\
\text { alkaloids, bitter principle, lactones } \\
\text { and flavonoids. }\end{array}$ & C. albicans, C. tropicalis, C. glabrata. & {$[78]$} \\
\hline Curcuma longa L. & Curcumin & C. albicans, C. tropicalis, C. glabrata. & {$[78]$} \\
\hline $\begin{array}{c}\text { Boesenbergia } \\
\text { pandurata }\end{array}$ & Geraniol and camphor & C. albicans & {$[90]$} \\
\hline $\begin{array}{l}\text { Coriandrum } \\
\text { sativum L. }\end{array}$ & Linalool & C. albicans, C. tropicalis & [91] \\
\hline $\begin{array}{c}\text { Piper } \\
\text { diospyrifolium }\end{array}$ & $\begin{array}{c}(E) \text {-Eudesma-6,11-diene, } \\
\gamma \text {-muuroleneandcaryophyllene-type } \\
(E) \text {-caryophyllene }\end{array}$ & $\begin{array}{l}\text { C. albicans, C. tropicalis, } \\
\text { C. parapsilosis }\end{array}$ & {$[92]$} \\
\hline Mentha piperita & $\begin{array}{l}\text { Menthol, menthyl acetate and } \\
\text { menthofuran }\end{array}$ & $\begin{array}{l}\text { C. albicans, C. tropicalis, C. krusei, } \\
\text { C. glabrata, C. dubliniensis, } \\
\text { C. parapsilosis, C. neoformans, } \\
\text { Aspergillus flavus, A. fumigatus, } \\
\text { A. clavatus, and A. oryzae } \\
\end{array}$ & [93] \\
\hline $\begin{array}{c}\text { Cymbopogon } \\
\text { citratus }\end{array}$ & Citral & Malassezia spp. & {$[81]$} \\
\hline
\end{tabular}

\subsubsection{Terpenes or Terpenoids}

Terpenoids are some of the substances in essential oils [94], and terpene compounds from natural vegetable oils are frequently monoterpenes (approximately $90 \%$ of the volatile oil) and sesquiterpenes. Other terpenoids, such as diterpenes, are found only in volatile oils and can be extracted using solvents [94].

Studies have indicated that terpenoids may show antioxidant and antimicrobial properties against pathogenic fungi, including Candida and dermatophytes [95-99]. However, there are few terpene compounds with well-established antifungal activity and well-described pharmacological properties [94]. Machumi [100] studied the antifungal activity of nine diterpenoids from Clerodendrum eriophyllum against Candida spp., C. neoformans and A. fumigatus and reported the isolation and structural determination of a new abietane diterpenoid (2-hydroxy-8,12-abietadiene-3,11,14-trione). They concluded that taxodione and 6-hydroxysalvinolone exhibited strong antifungal activity against C. neoformans. Furthermore, Amber et al. [101] observed that terpenes from Ocimum sanctum, including methyl chavicol and linalool, affected the synthesis of ergosterol and caused membrane cell 
damage in Candida species, which suggests that it may be a good antifungal agent. Isolated terpenes should be more thoroughly researched to establish the mechanism of their antifungal activity.

\subsection{Propolis}

Propolis is the generic name for a complex mixture of resinous substances collected from plants by bees. It is used in the beehive to coat the inner walls, to protect the entrance against intruders and to prevent the growth of fungi and bacteria [102]. The chemical composition of propolis is strongly influenced by the type of bee and vegetation and the season of the year [103,104]. Despite differences in propolis composition, studies at different times and in different regions have demonstrated its antifungal activity [105-107].

Research has demonstrated the antifungal activity of propolis against fungi such as Candida spp. [105,106,108,109]. A study by our group that compared the activities of propolis and fluconazole against Candida spp. isolated from the mouths of HIV-positive patients showed that propolis extract was able to inhibit yeast with a MIC lower than that of fluconazole (unpublished results) (Figure 1).

Figure 1. Results obtained by our group for propolis and fluconazole against Candida species isolated from HIV-positive patients.
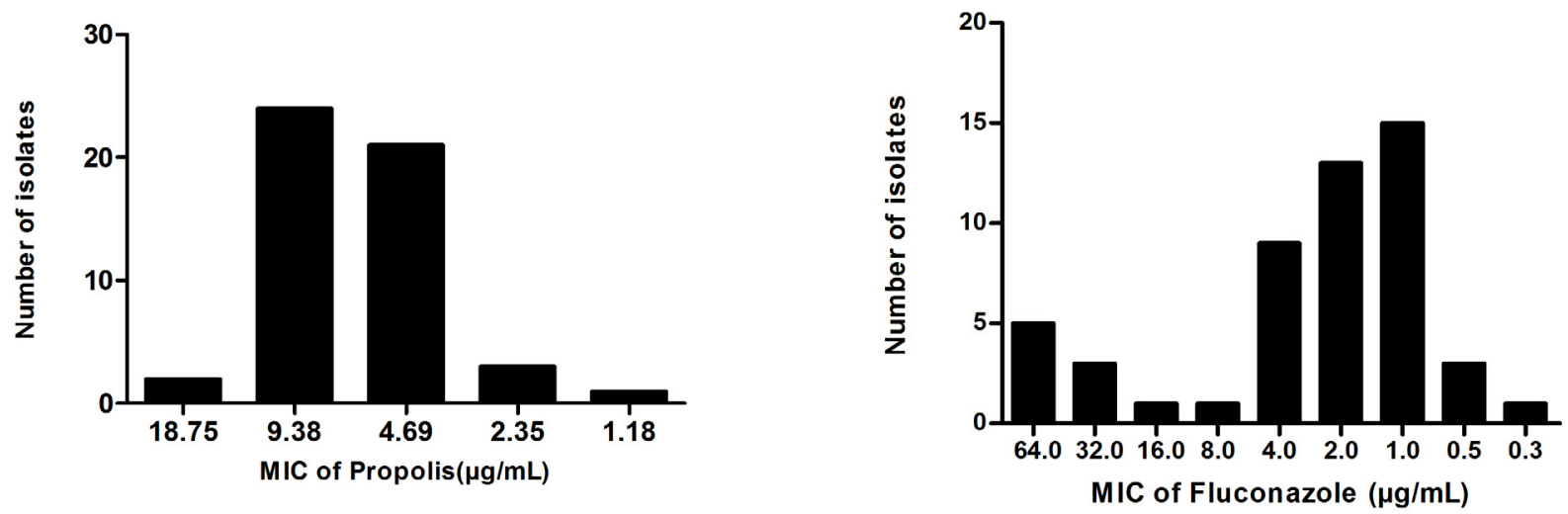

Propolis also showed antifungal activity against dermatophytes [105,110], C. neoformans [111], and onychomycosis [110] and exhibited a synergistic effect with macrophages against Paracoccidioides brasiliensis [112]. Further, propolis has advantages such as a low cost and lack of toxicity [110].

However, for some preparations, such as ethanolic propolis extracts show certain disadvantages, as a strong and unpleasant taste, aromatic odour and high ethanol concentration. To reduce these disadvantages, Avanço et al. [113] developed a method to prepare propolis via a microencapsulation process and concluded that ethylcellulose microparticles containing propolis are useful for developing aqueous dosage forms of propolis that lack the strong and unpleasant taste, aromatic odour and high ethanol concentration from the ethanolic extract. Dota et al. [114] evaluated the antifungal activity after propolis microencapsulation and observed that propolis microparticles and the ethanol extract were able to inhibit the growth of yeast, including that of yeasts resistant to azoles. 


\subsection{Ajoene Derived from Garlic}

The genus Allium contains over 300 plant species, and most of them belong to the Liliaceae family, which includes species of economic importance such as garlic (A. sativum L.), leek (A. ampeloprasum L. var. Porrum (L.) J. Gay), spring onion (A. fistulosum L.) and others. Currently, over 100 biologically active compounds have been derived from garlic, and most of them are organosulphur compounds, mainly ajoene. These compounds show a wide spectrum of activity that includes antimicrobial effects and beneficial effects on the cardiovascular and immune systems [115].

The major sulphur-containing compounds in garlic are $S$-allyl cysteine sulphoxide (alliin). When raw garlic is damaged, alliinase is released from the tissue and converted into primarily diallyl thiosulphinate (allicin) with a small amount of allyl methyl thiosulphinates. Ajoene $[(E, Z)-4,5,9-$ trithiadodeca-1,6,11-triene-9-oxide)] is derived from allicin. However, efficiently obtaining ajoene is dependent on the specific processing conditions for the garlic, which also applies to the isolation of other bioactive compounds [116,117].

Ajoene shows important antifungal activity against both yeasts and filamentous fungi [118-123]. According to the literature, the filamentous fungi Fusarium spp. are $100 \%$ resistant to itraconazole [124-126]. Our group evaluated the in vitro effect of ajoene against Fusarium spp. and obtained satisfactory results (Table 2).

Table 2. Evaluation of the in vitro antifungal susceptibility of 27 onychomycosis clinical isolates of Fusarium sp. to ajoene compared to itraconazole.

\begin{tabular}{ccc}
\hline \multirow{2}{*}{$\begin{array}{c}\text { Species } \\
\text { (No. of Isolates) }\end{array}$} & \multicolumn{2}{c}{ MIC Range $(\boldsymbol{\mu g} / \mathbf{m L})$} \\
\cline { 2 - 3 } Ajoene & Itraconazole \\
\hline Fusarium oxysporum (8) & $14.63-29.25$ & $16-16$ \\
Fusarium solani (8) & $3.65-29.25$ & $16-16$ \\
Fusarium sacchari (3) & $14.63-29.25$ & $16-16$ \\
Fusarium verticillioides (2) & 14.63 & $16-16$ \\
Fusarium chlamydosporum (1) & 29.25 & 16 \\
Fusarium proliferatum(1) & 14.63 & 16 \\
Fusarium incarnatum(1) & 29.25 & 16 \\
Fusarium napiforme (1) & 14.63 & 16 \\
Fusarium subglutinans (1) & 7.3 & 16 \\
C. parapsilosis ATCC 22019 (1) & 29.25 & 0.125 \\
\hline
\end{tabular}

Notes: Concentrations from 0.03 to $16 \mu \mathrm{g} / \mathrm{mL}$ for itraconazole and 3.65 to $29.2 \mu \mathrm{g} / \mathrm{mL}$ for ajoene were used. The breakpoints used for itraconazole were $\leq 0.125 \mu \mathrm{g} / \mathrm{mL}$, Susceptible strains; $0.25 \mu \mathrm{g} / \mathrm{mL}$ to $0.5 \mu \mathrm{g} / \mathrm{mL}$, Susceptible dose-dependent strains; and $\geq 1.0 \mu \mathrm{g} / \mathrm{mL}$, resistant strains. The reading was performed using a visual method, and the MIC was considered to be the concentration of ajoene or itraconazole that inhibited $100 \%$ of the growth of each yeast. Unpublished data obtained by Shinobu-Mesquita.

Other effects of ajoene were observed when tested against $P$. brasiliensis. It had the ability to block the transition from the mycelial phase to the yeast-like phase (an important mechanism in the pathogenicity of paracoccidioidomycosis) and efficiently controlled this disease in mouse experiments $[127,128]$. Furthermore, studies have shown that ajoene is effective for the topical treatment of superficial 
mycoses [129-131] and subcutaneous disease [132]. Thus, ajoene extract is an alternative for the treatment of the tested fungus and especially for onychomycosis caused by Fusarium spp.

\subsection{Saponins}

The name "saponin" is derived from sapo, the Latin word for soap, because these compounds have surfactant properties and form stable, soap-like foams when shaken in aqueous solution. These molecules are amphipathic glycosides with triterpene or steroid backbones. They are a large and structurally diverse group of bioactive natural products that are found primarily in plants, most commonly in dicots [133-137].

Many plants used in traditional medicine contain saponins, which are often responsible for the therapeutic action and protect against potential pathogens through their antimicrobial activity [138]. Saponins are extremely toxic to cold-blooded animals, but their oral toxicity in mammals is low $[139,140]$. Due to their toxicity to various organisms, saponins can be utilised for their insecticidal, antibiotic, fungicidal, and pharmacological properties. The wide chemical diversity of both triterpenoid and steroidal saponins has resulted in the renewed interest in and investigations of these compounds in recent years, particularly as potential chemotherapeutic agents [141].

The fractionation of the butanolic extract of the berries of Phytolacca tetramera Hauman yielded three monodesmosidic triterpenoid saponins with one, two or three sugars as the glycan moiety. The structures were established as phytolaccosides B, E and F (Figure 2). Phytolaccosides B and E showed antifungal activity against opportunistic human pathogenic fungi, and phytolaccoside B was the most active, mainly against T. mentagrophytes; in addition, it showed the broadest spectrum of action [142].

Figure 2. I solated saponins of butanolic extract from Phytolacca tetramera. The triterpenoid saponins with one, two or three sugars as the glycon moiety were established as phytolaccosides B, E and F, respectively. Adapted from Escalante et al. [142], for illustrative purposes only.

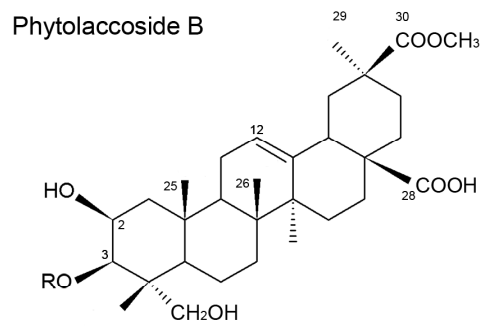

$R=\beta-D-x y l o p y r a n o s y l-$

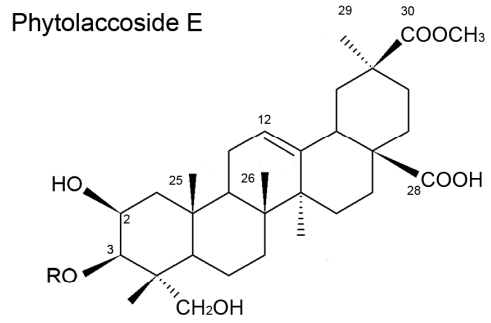

R= $\beta$-D-glucopyranosyl-(1-4)- $\beta$-D-xylopiranosyl -

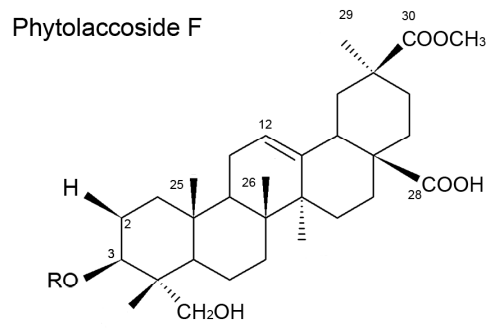

$\mathrm{R}=\alpha$-L-rhamnopyranosyl (1-2)- $\beta$-D-glucopyranosyl $(1 \rightarrow 2)-\beta-D-x y l o p y r a n o s y l-$

In 2010, Liberto et al. [143] studied the saponin-rich extract from Phytolacca dioica and its acid hydrolysate and major aglycone, as well as phytolaccagenin, and assayed their antifungal activity against $C$. albicans and $C$. neoformans. The extract showed no activity at concentrations up to $250 \mu \mathrm{g} / \mathrm{mL}$, but the hydrolysate, which contained sapogenins and included phytolaccagenin, and pure phytolaccagenin showed promising antifungal activity. 
The effect of the extracts of the aerial parts and roots of four Medicago species and 19 saponin compounds were studied by Houghton et al. [144]. All of the saponin extracts showed inhibitory effects on the growth of three dermatophytic species (M. gypseum, Trichophyton interdigitale and T. tonsurans), and T. tonsurans was the most susceptible. However, the aglycones showed less antifungal effect than the glycosides, which displayed a range of activity. The monodesmosidic glycosides of medicagenic acid were the most active compounds, particularly the 3-O- $\beta$-Lglucopyranoside, which displayed a MIC less than $0.09 \mathrm{mM}$ against all three fungi. Hederagenin and zanhic acid also showed low levels of activity.

Eight steroid saponins were isolated from Tribulus terrestris L., and their in vivo antifungal activities were tested against six fluconazole-resistant yeasts (C. albicans, C. glabrata, C. parapsilosis, C. tropicalis, C. krusei, and C. neoformans) [145,146]. Two compounds (Figure 3) were very effective against several pathogenic Candida species and $C$. neoformans [145]. Using phase contrast microscopy, Zhang et al. [146], demonstrated that saponin 1 (Figure 3) inhibited hyphal formation and destroyed the cell membrane. Thus, this saponin is therapeutically promising, particularly for patients who do not respond to conventional therapy.

Figure 3. Two steroid saponins from Tribulus terrestris L. that show in vitro antifungal activity. These saponins are tigogenin-3- $O-\beta$-D-xylopyranosyl- $(1 \rightarrow 2)-[\beta-\mathrm{D}-$ xylopyranosyl $(1 \rightarrow 3)]-\beta$-D-glucopyranosyl $\quad(1 \rightarrow 4)$-[ $\beta$-L-rhamnopyranosyl- $(1 \rightarrow 2)]-\beta$-Dgalactopyranoside (saponin 1), tigogenin-3-O- $\beta$-D-glucopyranosyl- $(1 \rightarrow 2)-[\beta$-Dxylopyranosyl-( $(1 \rightarrow 3)]$ - $\beta$-D-glucopyranosyl- $(1 \rightarrow 4)-\beta$-D-galactopyranoside $\quad($ saponin 2$)$. Adapted from Zhang et al., [146], for illustrative purposes only.

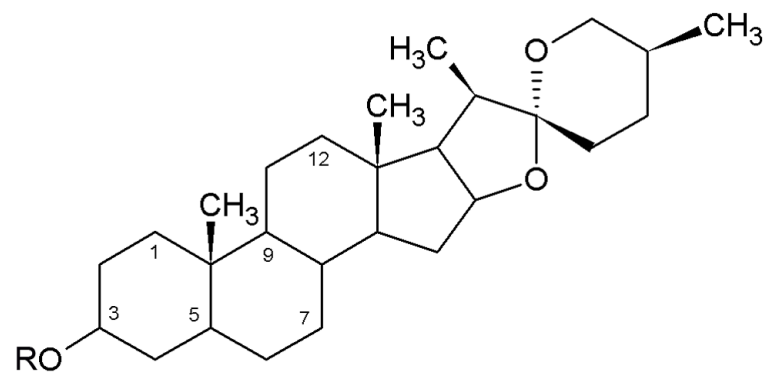

saponin 1 : $R=-\beta$-d-xylopyranosyl $(1 \rightarrow 2)-[\beta$-d-xylopyranosyl $(1 \rightarrow 3)]-\beta$-d-glucopyranosyl $(1 \rightarrow 4)-$

[ $\beta$-I-rhamnopyranosyl $(1 \rightarrow 2)]-\beta$-d-galactopyranoside

saponin 2: $R=-\beta$-d-glucopyranosyl $(1 \rightarrow 2)-[\beta$-d-xylopyranosyl $(1 \rightarrow 3)]-\beta$ - d-glucopyranosyl $(1 \rightarrow 4)$ - $\beta$-d-galactopyranoside

Using the Caenorhabditis elegans (nematode) model as a heterologous host, potential antifungal natural products including the identified saponins were tested. The results demonstrated that certain saponins affected nematode survival comparably to amphotericin B, and two saponins (A16 (aginoside) and A19) inhibited C. albicans at low concentrations. Moreover, when used in combination with photosensitising compounds, the fungus displayed increased susceptibility to photodynamic inactivation due to the ability of the saponins to increase cell permeability, which facilitated the penetration of the photosensitisers [147]. 
The extract of Sapindus saponaria L. is rich in saponins and is being studied by a group of researchers at the State University of Maringá. The main components of the $\mathrm{BuOH}$ extract (BUTE) of the pericarp of $S$. saponaria (two acylated triterpene saponins, S1 and S2, and also an acyclic oligoglycoside) have been identified. The hydroalcoholic extract (HE) and BUTE demonstrated excellent inhibitory and fungicidal activity in vitro against Candida spp. [148]. Furthermore, Damke et al. [149] demonstrated that these extracts had strong in vivo antifungal activity against Candida species. To summarise, research on plants containing saponins is promising and suggests that they could act as new antifungal therapies.

\subsection{Alkaloids}

Alkaloids from plants are a diverse group and show a broad spectrum of activity. A basic nitrogen is the only unifying structural feature of this wide range of compounds. Typical alkaloids are derived from plant sources, contain one or more nitrogen atoms (generally in a heterocyclic ring), and usually show significant pharmacological activity $[94,150]$.

The alkaloid 2-hydroxy-9-methoxyaporphine, isolated from the extract of Beilschmiedia species, showed potent activity against $C$. albicans with a MIC of $8 \mu \mathrm{g} / \mathrm{mL}$ [151]. Another plant, Chelidonium majus, contained the alkaloids 8-hydroxydihydrosanguinarine and 8-hydroxydihydrochelerythrine in its ethanol extract, and these compounds showed strong antifungal activity when tested against Candida spp. clinical isolates [152]. These alkaloids have MIC values that indicate antifungal activity, although more specific tests should be performed to confirm their safety and efficacy in vivo.

\subsection{Phenolic Compounds and Flavonoids}

Phenolic compounds are found in a large variety of plants, and they can be simple or complex structures containing at least one aromatic ring in which one or more hydrogens are substituted by a hydroxyl group. When the phenolic compounds are secondary metabolites of the plant, they are found to have a variety of structures, such as phenolic acids and coumarin derivatives and may be the water-soluble pigments of flowers, fruits and leaves. In addition, this class of compounds includes lignins and tannins, polymers with important functions in plants [94].

Phenolic compounds may be isolated from the ethanol extracts of different natural sources, such as plants, lichens and macroscopic fungi. Research conducted with Cetraria pinastri and Parmelia crinita, which are symbiotic organisms consisting of one fungi partner and one alga or Cyanobacteria (lichen) partner, showed a high level of phenolic compounds and activity against C. albicans and Penicillium verrucosum [153]. Among the compounds isolated from Phellinus spp., a macroscopic fungi, phenolic compounds showed substantial antimicrobial activity and inhibited the growth of Alternaria alternata [154].

Phenolic compounds from the extracts and essential oil of Elais guineensis showed antifungal activity against $C$. albicans when subjected to specific tests, including in vivo antifungal activity [155]. In another study, Kumar et al. [156] observed antimicrobial activity against C. albicans, A. niger, A. flavus and Alternaria solani for a methanolic extract from Bauhinia racemosa Lam, which contained $64.7 \mu \mathrm{g}$ of pyrocatechol equivalents of phenols in $1 \mathrm{mg}$ of extract. Moreover, the phenolic compounds eugenol, eugenyl acetate, $\beta$-caryophyllene, and 2-heptanone were isolated and 
characterised from the essential oil of Eugenia caryophyllata and exhibited antifungal activity against a large number of human pathogenic fungi [157].

Flavonoids are bioactive compounds with antioxidant and anti-inflammatory properties that are found in large quantities in certain plants as a result of their prevalence among secondary metabolites. These compounds represent one of the most important phenolic groups (polyphenols) and have a role in various functions, including the protection of plants against ultraviolet and visible light; protection against insects, fungi, viruses, and bacteria; the attraction of animals for pollination; and the action of plant hormones. In addition, they function as antioxidants, allelopathic agents and enzyme inhibitors [94].

Five prenylated flavonoids were isolated from the ethanol extract of the leaves of Maclura tinctoria (L.) Gaud and were evaluated against the AIDS-related opportunistic fungal pathogens C. albicans and C. neoformans. Two of these compounds showed inhibitory activity against $C$. albicans and C. neoformans, and another two were inactive against both organisms [158].

Another flavonoid, a flavone glycoside isolated from the ethanolic extract of Vitex negundo, showed significant antifungal activity against $T$. mentagrophytes and C. neoformans [159]. Curcumin, a flavonoid found in the Curcuma longa extract, showed antifungal activity against the yeast form of $P$. brasiliensis. In addition, this flavonoid was more efficient than fluconazole in inhibiting the adhesion of Candida species to human buccal epithelial cells, and it was able to inhibit the growth of C. neoformans, Sporothirx schenckii and clinical isolates of C. dubliniensis [160].

Finally, extracts from Dorstenia mannii (Moraceae), a medicinal herb traditionally used for the treatment of many diseases, contains the flavonoids dorsmanin A, B and C, 6,8-diprenyleriodictyol, dorsmanin $\mathrm{E}, \mathrm{F}, \mathrm{G}$, and dorsmanin $\mathrm{I}$, which were isolated and tested against yeast. All of these flavonoids and the crude methanol extract showed activity against $C$. albicans [161].

\subsection{Coumarins and Xanthones}

Coumarins are widely distributed in plants but can also be found in fungi and bacteria. Structurally, acid lactones are $O$-hydroxycinnamic acids, and the simplest representative is coumarin. Approximately 1,300 coumarins have been isolated from natural sources, and their pharmacological, biochemical and therapeutic applications are dependent on the particular substitution patterns [94].

Studies of three preparations from the essential oil of Citrus bergamia (bergamot natural essence, furocoumarin-free extract and the distilled extract) showed antifungal activity against dermatophytes and yeast pathogens [162-164]. Bergamot oil is directly obtained from the fruit and consists of a volatile fraction (93\%-96\%), whose main components are, with approximate percentages, limonene (40\%), linalool $(8 \%)$ and linalyl acetate $(28 \%)$, and a non-volatile fraction $(4 \%-7 \%)$ consisting primarily of coumarins and psoralens (i.e., bergamottin, citroptene, bergaptene, etc.) [163,164]. The furocoumarin-free extract (bergaptene-free) and distilled extract (absolutely devoid of non-volatile residues) were more active than the natural essence against all of the species tested [162].

Xanthones are simple three-membered ring compounds that are mainly found as secondary metabolites in higher plants and microorganisms. Xanthones have very diverse biological profiles, including antihypertensive, antioxidative, antithrombotic, anticancer and antimicrobial activities, depending on their exact structures, which are diverse as a result of differences in the substituents on the ring system. The notable structural scaffold and pharmacological importance of xanthone 
derivatives have attracted many scientists to isolate or synthesise xanthone compounds for study as novel drug candidates [165-167].

Four xanthones have been isolated from the aerial parts of Monnina obtusifolia. The structures were established on the basis of their spectral data and that of their derivatives. One compound, 1,3,5-trihydroxy-2-methoxyxanthone, inhibited the growth of T. mentagrophytes and Cladosporium cucumerinum; another, 1,3-dihydroxy-2,5-dimethoxyxanthone, showed interesting activity against T. mentagrophytes [168]. Furthermore, some active xanthone derivative compounds showed good activity against fungi, making them promising candidates for further pharmacological and clinical studies $[169,170]$.

\subsection{Lignans}

Lignans are phenolic plant compounds found in high concentrations in flax and sesame seeds and in lower concentrations in grains, other seeds, fruits and vegetables. Lignans are stereospecific dimers of cinnamic alcohols (monolignols) bonded at carbon 8 (C8-C8) that are derived in the phenylpropanoid pathway and formed through phenolic oxidative coupling processes. In the plant, lignans (monolignol dimers) usually occur in the free state or bound to sugars, and diglucosides of pinoresinol, secoisolariciresinol, and syringaresinol are common. Lignans, neolignans and their analogues are involved in plant defence (as antioxidants, biocides, phytoalexins, etc.), provide protection against diseases and pests and possibly participate in plant growth control [94,171].

Styraxjaponoside $\mathrm{C}$ is a glycoside derivative of lignans from the stem bark of Styrax japonica $\mathrm{S}$. et $\mathrm{Z}$ and has shown activity against $C$. albicans, inhibiting mycelial growth with low cytotoxicity to human erythrocytes [172,173]. According to the literature, Piper regnellii roots contain several phenylpropanoids and dihydrobenzofuran neolignans, including $(+)$-conocarpan as the primary constituent. To investigate the antifungal activity of Piper regnellii leaf extracts, Koroishi et al. [174] evaluated the antidermatophytic activity of this extract as well as that of the isolated compound eupomatenoid-5 from the crude hydroalcoholic extract in vitro and observed that the pure compounds and eupomatenoid-5 showed strong activity against T. rubrum, indicating that the plant should be investigated for possible antifungal agents.

\subsection{Tannins}

Tannins are particularly important gustatory components that are responsible for the astringency of many fruits and vegetables. Tannin-protein binding is the basis for the ability of tannins to control insects, fungi and bacteria as well as their pharmacological activities [94].

Phytochemical investigation of Terminalia mollis and Terminalia brachystemma resulted in the isolation of many compounds, including the tannin ellagitannin punicalagin, which showed activity against C. parapsilosis, C. krusei and C. albicans [175].

Stryphnodendron adstringens (Mart.) Coville, Leguminosae occurs in the central region of Brazil. Stem bark from this plant is popularly used as an anti-inflammatory and astringent and in the treatment of wounds and vaginal infections [176,177]. The antifungal activities of a crude extract and the fractions and subfractions from $S$. adstringens (Mart.) Coville were investigated. These extracts showed moderate antifungal activity against $C$. albicans and low cytotoxicity to murine melanoma 
cells [178]. This extract was also assayed against C. neoformans [179] and interfered with important factors for virulence, including growth, capsule size, and pigmentation.

\subsection{Secondary Metabolites}

A large number of products derived from the secondary metabolism of various microorganisms have been reported, and many of them are being exploited by the pharmaceutical industry as potent antibiotics [180,181]. Thus, it is important to emphasise the findings of Phongpaichit et al. [182], who studied endophytic fungi from Garcinia spp. and observed that the secondary metabolites from this genus showed antifungal activity against relevant pathogenic fungi ( $C$. albicans, C. neoformans and M. gypseum). Another group studied the marine actinomycete Nocardia dassonvillei and identified a secondary metabolite, $\mathrm{N}$-(2-hydroxyphenyl)-2-phenazinamine (NHP) [183], with significant antifungal activity against $C$. albicans.

$\mathrm{Xu}$ et al. [184] evaluated the chemical composition and bioactivity of the extract from Paecilomyces sp. isolated from Panax ginseng and its activity against T. rubrum, C. albicans, C. neoformans and A. fumigatus. This extract showed activity against two of these fungi, but it was not effective against $A$. fumigatus. Extracts derived from Paecilomyces sp. and ginseng samples contained the same compound, falcarinol, providing evidence that endophytes produce metabolites which are the same or similar to those of their hosts.

\section{Perspectives}

As previously discussed, many available drugs, including antifungals, were discovered from random observations and/or a search of synthetic or natural compounds [45]. Studies of structure-activity relationships permitted chemical modifications, generating new compounds with improved pharmacological characteristics. Historically, the drug-development process has utilised high-throughput screening (HTS), in which large number of compounds are evaluated to identify those that are biologically active $[185,186]$.

Some studies utilised the HTS strategy to develop new antifungal agents. $\beta$-1,6-glucan synthesis inhibitors, including the pyridobenzimidazole derivative D75-4590, were obtained using high-throughput methodologies with a cell-based assay system and a chemical library of approximately 100,000 small molecules. These compounds were only active against Candida species [187]. In 2010, two compounds derived from D75-4590 were obtained, D11-2040 and D21-6076. Fungistatic activity was observed against Candida species, primarily non-C. albicans Candida (NCAC). However, no significant inhibitory effects were observed against $C$. neoformans, Trichosporon spp. or filamentous fungi [188]. Takeshita and colleagues identified another pyridobenzimidazole derivative with antifungal activity. An SAR study revealed that a basic substituent at the $\mathrm{C}-1$ position and a cyano group at the C-4 position were essential for antifungal activity; however, these compounds were only active against NCAC species [46]. Kuroyanagi et al. [47] synthesised triazolopyridine derivatives with antifungal activity against NCAC species, especially $C$. glabrata. The development of $\beta$-1,6-glucan synthesis inhibitors has shown promise, particularly for species resistant to conventional antifungal agents in candidaemia treatment, although their use is restricted to Candida species. 
Other benzimidazole derivatives have been identified by HTS methodologies. (S)-2-Aminoalkylbenzimidazole derivatives were found to be effective against Candida spp. at low micromolar concentrations using an HTS strategy with an activity-selectivity assay, which analyses both the antifungal activity and compatibility with HeLa cells in the same assay. Structure-activity relationship studies showed that the $(S)$-stereoisomers had effective antifungal activity [189]. Complementary studies of this group [190] showed that this new lead structure has high antifungal activity against clinical isolates of several Candida species. In addition, transcriptional profiling has shown that this compound is a potential inhibitor of the ergosterol pathway, in contrast to other benzimidazole derivatives, which target microtubules.

Chaturvedi et al. [191] selected 27 compounds with antifungal activity against Geomyces destructans, the etiologic agent of geomycosis in bats, from a library of 1920 structurally diverse compounds (drugs, experimentally active compounds, and pure natural products). Some molecules showed significant antifungal activity, but this information was not novel because the selected compounds had previously been described as antifungals, fungicides and biocides. Similarly, other cases have been reported in which HTS methodologies have been used for the rapid identification of potential therapeutic agents from libraries of known drugs and pharmaceutically active compounds that have been approved by the FDA [192].

Even with the evolution and emergence of new methodologies for HTS, these techniques are time consuming and expensive, especially when the tests are based on cellular assays [193]. Various computational approaches are available to contribute to HTS technologies. Among these, virtual screening (VS) is one of the most popular. This in silico methodology contributes to the research on and development of new drugs by allowing the efficient screening of millions of chemical compounds in libraries at reduced cost [194-196]. Additionally, VS technology allows the development of compounds that are different from those that have been patented. Thus, alternatives can be found without performing HTS and experimentally testing thousands of compounds [197].

In the post-genomic era, the advent of new technologies has generated an extraordinary amount of data and created more possibilities for drug development [45,198,199]. The identification of the molecular targets of antifungal drugs and elucidating their mechanisms of action in the fungus is an important undertaking not only for the development of novel drugs but also for the development of new pharmacological probes that can be used to investigate the basic biology of fungal pathogens [199,200]. After a new molecular target has been determined, new therapeutic agents may be identified by analysing the interaction of the candidate compounds with three-dimensional models of the target proteins [201,202].

Between 1999 and 2008, the FDA approved 183 small-molecule drugs. Despite the possible limitations of a target-centric approach to drug discovery, these approaches led to the discovery of 17 of the 50 first-in-class small molecule new molecular entities (NMEs). However, the approved small molecules do not include antifungals [203]. New antifungal development by this approach still seems to be in the preliminary stages, given that few studies are found in the literature, and those that exist are at the basic research stage [204-206].

Virtual screening studies have been used to select inhibitors of the CYP53 family of cytochrome P450 enzymes, which do not have a homologue in higher eukaryotes. From the 143,000 compounds selected for docking experiments, eight compounds showed promising results in in vitro assays. The 
best compound was (3-methyl-4-(1H-pyrrol-1-yl)benzoic acid, which was predicted to be an inhibitor of a fungal-specific enzyme and was thus a promising new lead for antifungal development [204]. However, these studies are still preliminary, considering that the antifungal activity assays were performed only with Cochliobolus lunatus using agar diffusion methods. Thus, additional experiments showing antifungal activity against several human pathogens by standardised methodology are still necessary. Sheng and collaborators identified four compounds that are more potent than fluconazole, itraconazole, and voriconazole against $C$. albicans and are active against other important human pathogenic fungi (C. tropicalis, C. neoformans and dermatophytes species). These results reveal the efficiency of the structure-based optimisation of novel azole antifungal agents and indicates that they are promising leads for the design of new drugs selected by VS strategies [207].

Recent technological advances have yielded increasing amounts of available data, not only of genomes and proteomes but also of host-pathogen interactions and the mechanisms of drug action. Therefore, rational antifungal drug design is possible. These new approaches have contributed during different stages of antifungal development because they optimise existing compounds to direct the process (new drug against new target). Researchers have primarily attempted to optimise the currently available drugs, especially the azole class, using molecular chemistry and bioinformatics [208-210]. Other investigators have focused on novel drug targets for the development of therapeutic options to obtain more specific compounds [211,212]. Additionally, advances in biotechnology and nanotechnology have contributed to the development of drugs that have already aided in the treatment of invasive fungal infections with worldwide relevance [213-215].

\section{Conclusions}

In summary, there are many on-going efforts in the search for new compounds with potential antifungal activity. Some of these compounds may become future prototypes of new antifungal drugs. However, more research is needed to ensure reliable results. There are diverse techniques for obtaining extracts from plants; these exhibit differences in the extraction parameters, including the solvent used, thus generating aqueous or hydroalcoholic mixtures, and utilise various extraction procedures, including infusion, decoction or maceration. These technical approaches have allowed compounds with different chemical characteristics to be isolated. Therefore, it is difficult to compare studies. Interlaboratory variability is also an issue.

Similarly, the reported antifungal actions seem to be satisfactory, but characteristics of the natural products influence the assays used to determine the antifungal activity. Because there are no standard protocols, researchers modify the procedures used in previous studies; however, each group focuses on what is important to that individual group; thus, the results obtained are not comparable. For example, we found publications using the agar diffusion test, which is ineffective because the molecules tested have different diffusion properties. Thus, it is impossible to evaluate the results of this assay and determine the antifungal activity.

It is interesting to note that the studies have generally been conducted on a few fungal isolates; therefore, it is necessary to perform further testing with a larger group of fungi including various genera and species of yeasts and filamentous fungus of medical interest. These complementary studies are essential because the antifungal action of a drug may vary according to the fungal species. This 
variation could result in treatment failure when the identification of the agent responsible for the infection is performed incorrectly and, consequently, incorrect drugs are used. Another problem is the selection of the species for the antifungal activity assays. If the focus is the treatment of human and/or animal mycoses, these assays should be carried out using the human or animal pathogenic fungi, at least for the most prevalent diseases. However, many studies have used saprophytes or environmental fungi in their antifungal activity evaluations.

It is important to highlight the importance of reproducibility and the correlation between the in vitro and in vivo activity. In vivo studies simulating fungal infection could confirm the antifungal action of these compounds, and studies of pharmacokinetics and pharmacodynamics could indicate the effectiveness of a possible treatment. There are few studies on conventional or alternative animals using natural products.

Another critical problem concerns the complexity of the natural products that have been evaluated. In general, they are complex mixtures from crude extracts or essential oils. It is important to isolate the specific compound responsible for the antifungal action and elucidate the mechanism of action of each isolated compound. It would be interesting to know if a specific compound acts on the cell wall or the cytoplasmic membrane or if it inhibits a specific pathway. New molecules open up new possibilities, and molecules capable of acting on specific targets that are not shared with the host would reduce the cytotoxicity and consequent side effects. This requires understanding the mechanism of action of the compound.

Current strategies for the development of new antifungal agents by biotechnology-related approaches seem promising, but these techniques are time consuming and expensive. They are also in their infancy for use in antifungal drug development, given that few studies are found in literature.

Finally, all of the studies cited have great potential for the development of new drugs, but most studies have been performed with molecules, extracts, and oils. Research regarding the toxicity of these compounds must be emphasised, especially concerning their pharmacodynamic characteristics and the potential implications of pharmacogenomics in predicting responses to these treatments. In other words, the development of new options for antifungal drugs is mandatory in view of the increase in fungal infections and their mortality rates. This process is a challenge to researchers and the pharmaceutical industry, but the recent application of biotechnological approaches has facilitated new discoveries.

\section{Acknowledgments}

The authors acknowledge Coordenação de Aperfeiçoamento de Pessoal de Nível Superior (CAPES), Conselho Nacional de Desenvolvimento Científico e Tecnológico (Cnpq), and Fundação Auraucária.

\section{Conflicts of Interest}

The authors declare no conflict of interest. 


\section{References}

1. Nucci, M.; Queiroz-Telles, F.; Alvarado-Matute, T.; Tiraboschi, I.N.; Cortes, J.; Zurita, J.; Guzman-Blanco, M.; Santolaya, M.E.; Thompson, L.; Sifuentes-Osornio, J.; et al. Epidemiology of candidemia in Latin America: A laboratory-based survey. PLoS One 2013, 8, e59373.

2. Arendrup, M.C.; Dzajic, E.; Jensen, R.H.; Johansen, H.K.; Kjældgaard, P.; Knudsen, J.D.; Kristensen, L.; Leitz, C.; Lemming, L.E.; Nielsen, L. Epidemiological changes with potential implication for antifungal prescription recommendations for fungaemia: Data from a nationwide fungaemia surveillance programme. Clin. Microbiol. Infect. 2013, 19, 343-353.

3. Butts, A.; Krysan, D.J. Antifungal drug discovery: Something old and something new. PLoS Pathog. 2012, 8, e1002870.

4. Shao, P.L.; Huang, L.M.; Hsueh, P.R. Recent advances and challenges in the treatment of invasive fungal infections. Int. J. Antimicrob. Agents 2007, 30, 487-495.

5. Ashcroft, D.M.; Po, A.L.W. Herbal remedies. Pharmacoeconomics 1999, 16, 321-328.

6. Kathiravan, M.K.; Salake, A.B.; Chothe, A.S.; Dudhe, P.B.; Watode, R.P.; Mukta, M.S.; Gadhwe, S. The biology and chemistry of antifungal agents: A review. Bioorg. Med. Chem. 2012, 20, 5678-5698.

7. Paiva, J.A.; Pereira, J.M. New antifungal antibiotics. Curr. Opin. Infect. Dis. 2013, 26, 168-174.

8. Iwu, M. International conference on ethnomedicine and drug discovery. J. Altern. Complem. Med. 2000, 6, 3-5.

9. Orafidiya, L.O.; Oyedele, A.O.; Shittu, A.O.; Elujoba, A.A. The formulation of an effective topical antibacterial product containing Ocimum gratissimum L. leaf essential oil. Int. J. Pharm. 2001, 224, 177-183.

10. Hernández Díaz, L.; Rodríguez Jorge, M. Actividad antimicrobiana de plantas que crecen en cuba. Rev. Cuba. Plant. Med. 2001, 6, 44-47.

11. Nakamura, C.V.; Ishida, K.; Faccin, L.C.; Cortez, D.A.C.G.; Rozental, S.; de Souza, W.; Ueda-Nakamura, T. In vitro activity of essential oil from Ocimum gratissimum L against four Candida species. Res. Microbiol. 2004, 155, 579-586.

12. Wieder, L.M. Fungistatic and fungicidal effects of two wood-preserving chemicals on human dermatophytes: Ortho ( 2 chlorophenyl) phenol sodium and tetrachlorphenol sodium. Arch. Derm. 1935, 31, 644-657.

13. Davies, W.H.; Sexton, W.A. Chemical constitution and fungistatic action of organic sulphur compounds. Biochem. J. 1946, 40, 331-334.

14. Hopkins, J.G.; Fisher, J.K.; Hillegas, A.B.; Ledin, R.B.; Rebell, G.C.; Camp, E. Fungistatic agents for treatment of dermatophytosis. J. Invest. Dermatol. 1946, 7, 239-253.

15. Lamb, J.H. Combined therapy in histoplasmosis and coccidioidomycosis; methyltestosterone and meth-dia-mer-sulfonamides. AMA Arch. Derm. Syphilol. 1954, 70, 695-712.

16. Oxford, A.E.; Raistrick, H.; Simonart, P. Griseofulvin, $\mathrm{C}_{17} \mathrm{H}_{17} 0_{6} \mathrm{Cl}$, a metabolic product of Penicillium griseo-fulvum Dierckx. Biochem. J. 1939, 33, 240-248.

17. Odds, F.C. Antifungal agents: Their diversity and increasing sophistication. Mycologist 2003, 17, $51-55$. 
18. Brown, Hazen, E.L.; Mason, A. Effect of fungicidin (nystatin) in mice injected with lethal mixtures of aureomycin and Candida albicans. Science 1953, 117, 609-610.

19. Brown, R.; Hazen, E.L. Production of actidione by Streptomyces noursei. Antibiot. Annu. 1955, 3, 245-248.

20. Brown, R.; Hazen, E.L. Present knowledge of nystatin, an antifungal antibiotic. Trans. N. $Y$. Acad. Sci. 1957, 19, 447-456.

21. Brezis, M.; Rosen, S.; Silva, P.; Spokes, K.; Epstein, F.H. Polyene toxicity in renal medulla: Injury mediated by transport activity. Science 1984, 224, 66-68.

22. Gupta, A.K.; Tomas, E. New antifungal agents. Dermatol. Clin. 2003, 21, 565-576.

23. Grunberg, E.; Berger, J.; Titsworth, E. Chemotherapeutic studies on a new antifungal agent, x-5079c, effective against systemic mycoses. Am. Rev. Respir. Dis. 1961, 84, 504-506.

24. Li, M.; Liao, Y.; Chen, M.; Pan, W.; Weng, L. Antifungal susceptibilities of Cryptococcus species complex isolates from aids and non-aids patients in southeast China. Braz. J. Infect. Dis. 2012, 16, 175-179.

25. Heeres, J.; Meerpoel, L.; Lewi, P. Conazoles. Molecules 2010, 15, 4129-4188.

26. Gleason, T.G.; May, A.K.; Caparelli, D.; Farr, B.M.; Sawyer, R.G. Emerging evidence of selection of fluconazole-tolerant fungi in surgical intensive care units. Arch. Surg. 1997, 132, 1197-1201.

27. Salci, T.P.; Gimenes, M.; dos Santos, C.A.; Svidzinski, T.I.E.; Caparroz-Assef, S.M. Utilization of fluconazole in an intensive care unit at a university hospital in Brazil. Int. J. Clin. Pharm. 2013, 35, 176-180.

28. Odds, F.C.; Brown, A.J.P.; Gow, N.A.R. Antifungal agents: Mechanisms of action. Trends Microbiol. 2003, 11, 272-279.

29. Barrett, D. From natural products to clinically useful antifungals. Biochim. Biophys. Acta 2002, 1587, 224-233.

30. Denning, D.W. Echinocandin antifungal drugs. Lancet 2003, 362, 1142-1151.

31. Cappelletty, D.; Eiselstein-McKitrick, K. The echinocandins. Pharmacotherapy 2007, 27, 369-388.

32. Pappas, P.G.; Kauffman, C.A.; Andes, D.; Benjamin, D.K., Jr.; Calandra, T.F.; Edwards, J.E., Jr.; Filler, S.G.; Fisher, J.F.; Kullberg, B.J.; Ostrosky-Zeichner, L. Guías de práctica clínica para el manejo de la candidiasis: Actualización del 2009, de la infectious diseases society of america. Clin. Infect. Dis. 2009, 48, 503-537.

33. Herreros, E.; Martinez, C.M.; Almela, M.J.; Marriot, M.S.; de las Heras, F.G.; Gargallo-Viola, D. Sordarins: In vitro activities of new antifungal derivatives against pathogenic yeasts, Pneumocystis. carinii and filamentous fungi. Antimicrob. Agents Chemother. 1998, 42, 2863-2869.

34. Clemons, K.V.; Stevens, D.A. Efficacies of sordarin derivatives gm193663, gm211676, and gm237354 in a murine model of systemic coccidioidomycosis. P6. Antimicrob. Agents Chemother. 2000, 44, 1874-1877.

35. Castro, J.; Cuevas, J.C.; Fiandor, J.M.; Fraile, M.T.; Gomez De Las Heras, F.; Ruiz, J.R. Antifungal sordarins. Part 3: Synthesis and structure-activity relationships of 2', $3^{\prime}$-fused oxirane derivatives. Bioorg. Med. Chem. Lett. 2002, 12, 1371-1374. 
36. Kamai, Y.; Kakuta, M.; Shibayama, T.; Fukuoka, T.; Kuwahara, S. Antifungal activities of r-135853, a sordarin derivative, in experimental candidiasis in mice. Antimicrob. Agents Chemother. 2005, 49, 52-56.

37. Hanadate, T.; Tomishima, M.; Shiraishi, N.; Tanabe, D.; Morikawa, H.; Barrett, D.; Matsumoto, S.; Ohtomo, K.; Maki, K. Fr290581, a novel sordarin derivative: Synthesis and antifungal activity. Bioorg. Med. Chem. Lett. 2009, 19, 1465-1468.

38. Ostrosky-Zeichner, L.; Casadevall, A.; Galgiani, J.N.; Odds, F.C.; Rex, J.H. An insight into the antifungal pipeline: Selected new molecules and beyond. Nat. Rev. Drug Discov. 2010, 9, 719-727.

39. Pfaller, M.A.; Castanheira, M.; Messer, S.A.; Moet, G.J.; Jones, R.N. Echinocandin and triazole antifungal susceptibility profiles for Candida spp., Cryptococcus neoformans and Aspergillus. fumigatus: Application of new CLSI clinical breakpoints and epidemiologic cutoff values to characterize resistance in the Sentry Antimicrobial Surveillance Program (2009). Diagn. Microbiol. Infect. Dis. 2011, 69, 45-50.

40. Pfaller, M.A.; Duncanson, F.; Messer, S.A.; Moet, G.J.; Jones, R.N.; Castanheira, M. In vitro activity of a novel broad-spectrum antifungal, E1210, tested against Aspergillus spp. determined by CLSI and EUCAST broth microdilution methods. Antimicrob. Agents Chemother. 2011, 55, $5155-5158$.

41. Hata, K.; Horii, T.; Miyazaki, M.; Watanabe, N.-A.; Okubo, M.; Sonoda, J.; Nakamoto, K.; Tanaka, K.; Shirotori, S.; Mura, N.; et al. Efficacy of oral E1210, a new broad-spectrum antifungal with a novel mechanism of action, in murine models of candidiasis, aspergillosis, and fusariosis. Antimicrob. Agents Chemother. 2011, 55, 4543-4551.

42. Miyazaki, M.; Horii, T.; Hata, K.; Watanabe, N.A.; Nakamoto, K.; Tanaka, K.; Shirotori, S.; Murai, N.; Inoue, S.; Matsukura, M.; et al. In vitro activity of E1210, a novel antifungal, against clinically important yeasts and molds. Antimicrob. Agents Chemother. 2011, 55, 4652-4658.

43. U.S. Food and Drug Administration. Informations for Clinical Investigators (INDs). Available online: http://www.fda.gov/Drugs/DevelopmentApprovalProcess/ HowDrugsareDevelopedandApproved/ApprovalApplications/InvestigationalNewDrugINDApplic ation/ucm176259.htm (accessed on 16 January 2014).

44. Hope, P.R.P. Intellectual property protections are vital to continuing innovation in the biopharmaceutical industry. 2013. Available online: http://www.phrma.org/innovation/ intellectual-property (accessed on 16 January 2014).

45. Drews, J. Drug discovery: A historical perspective. Science 2000, 287, 1960-1964.

46. Takeshita, H.; Watanabe, J.; Kimura, Y.; Kawakami, K.; Takahashi, H.; Takemura, M.; Kitamura, A.; Someya, K.; Nakajima, R. Novel pyridobenzimidazole derivatives exhibiting antifungal activity by the inhibition of beta-1,6-glucan synthesis. Bioorg. Med. Chem. Lett. 2010, 20, 3893-3896.

47. Kuroyanagi, J.; Sugimoto, Y.; Fujisawa, T.; Morita, C.; Suzuki, T.; Kawakami, K.; Takemura, M. Novel antifungal agents: Triazolopyridines as inhibitors of beta-1,6-glucan synthesis. Bioorg. Med. Chem. 2010, 18, 5845-5854.

48. Svidzinski, T.I.E.; Franco, S.L.; Moura, L.M.P.; Oliveira, A.C.P.; Longhini, R. Obtenção de extratos de própolis sobre diferentes condições e avaliação de sua atividade antifúngica. Rev. Bras. Farmacogn. 2005, 17, 388-395. 
49. Franco, S.L.; Svidzinski, T.I.E.; Ogawa, S.E.N.; Novelo, C.R. Composições Farmacêuticas com Atividade Antifúngica Contendo Extratos de Cymbopogon nardus, Processo de Obtenção dos Extratos de Cymbopogon nardus e seus usos. Braz. Patent number BRPI0702622 (WO2008113146), 25 September 2008.

50. Ferreira, I.C.P.; Estivalet, T.I.E.; Tsuzuki, J.C.; Cortez, D.A.G. Uso do Extrato da Planta Sapindus saponaria e de seus Princípios Ativos Para o Controle e Tratamento de Infecções por Fungos. Braz. Patent BRPI0506075, 12 September 2005.

51. Shinobu-Mesquita, C.S.; Bertoni, T.A.; Guilhermetti, E.; Svidzinski, T.I.E.I.E. Antifungal activity of the extract of Curcuma zedoaria (christm.) roscoe, zingiberaceae, against yeasts of the genus Candida isolated from the oral cavity of patients infected with the human immunodeficiency virus. Rev. Bras. Farmacogn. 2011, 21, 128-132.

52. Pessini, G.L.; Holetz, F.B.; Sanches, N.R.; Cortez, D.A.G.; Dias Filho, B.P.; Nakamura, C.V. Avaliação da atividade antibacteriana e antifúngica de extratos de plantas utilizados na medicina popular. Rev. Bras. Farmacogn. 2003, 13, 21-24.

53. Tempone, A.G.; Sartorelli, P.; Teixeira, D.; Prado, F.O.; Calixto, I.A.R.L.; Lorenzi, H.; Melhem, M.S.C. Brazilian flora extracts as source of novel antileishmanial and antifungal compounds. Mem. Inst. Oswaldo Cruz 2008, 103, 443-449.

54. Rajeh, M.A.B.; Zuraini, Z.; Sasidharan, S.; Latha, L.Y.; Amutha, S. Assessment of Euphorbia hirta L. leaf, flower, stem and root extracts for their antibacterial and antifungal activity and brine shrimp lethality. Molecules 2010, 15, 6008-6018.

55. Polaquini, S.R.B.; Svidzinski, T.I.E.; Kemmelmeier, C.; Gasparetto, A. Effect of aqueous extract from neem (Azadirachta indica A. Juss) on hydrophobicity, biofilm formation and adhesion in composite resin by Candida albicans. Arch. Oral Biol. 2006, 51, 482-490.

56. Niño, J.; Mosquera, O.M.; Correa, Y.M. Antibacterial and antifungal activities of crude plant extracts from colombian biodiversity. Rev. Biol. Trop. 2012, 60, 1535-1542.

57. Zabka, M.; Pavela, R.; Gabrielova-Slezakova, L. Promising antifungal effect of some euro-asiatic plants against dangerous pathogenic and toxinogenic fungi. J. Sci. Food Agric. 2011, 91, 492-497.

58. Madhumitha, G.; Saral, A.M. Preliminary phytochemical analysis, antibacterial, antifungal and anticandidal activities of successive extracts of Crossandra. infundibuliformis. Asian Pac. J. Trop. Med. 2011, 4, 192-195.

59. Karimi, E.; Jaafar, H.Z.E.; Ahmad, S. Antifungal, anti-inflammatory and cytotoxicity activities of three varieties of Labisia pumila benth: from microwave obtained extracts. BMC Complement. Altern. Med. 2013, 13, 20.

60. Hamza, O.J.M.; van den Bout-Van den Beukel, C.J.P.; Matee, M.I.N.; Moshi, M.J.; Mikx, F.H.M.; Selemani, H.O.; Mbwambo, Z.H.; van der Ven, A.J.A.M.; Verweij, P.E. Antifungal activity of some tanzanian plants used traditionally for the treatment of fungal infections. J. Ethnopharmacol. 2006, 108, 124-132.

61. Phongpaichit, S.; Subhadhirasakul, S.; Wattanapiromsakul, C. Antifungal activities of extracts from thai medicinal plants against opportunistic fungal pathogens associated with aids patients. Mycoses 2005, 48, 333-338. 
62. Naghdi, B.H.; Soroushzadeh, A.; Rezazadeh, S.A.; Sharifi, M.; Ghalavand, A.; Rezaei, A. Evaluation of phytochemical and production potential of borage (Borago. officinalis L.) during the growth cycle. J. Med. Plants 2008, 7, 37-43.

63. Binns, S.E.; Arnason, J.T.; Baum, B.R. Phytochemical variation within populations of Echinacea angustifolia (asteraceae). Biochem. Sys. Ecol. 2002, 30, 837-854.

64. Zhao, Y.P.; Li, J.H.; Yang, S.T.; Fan, J.; Fu, C.X. Effects of postharvest processing and geographical source on phytochemical variation of Corydalis rhizoma. Chin. Herbal Med. 2013, $5,151-157$.

65. Silva-Santos, A.; Antunes, A.M.S.; Bizzo, H.R.; d'Avila, L.A. A participação da indústria óleo-citrícola na balança comercial brasileira. Rev. Bras. Plant. Med. 2006, 8, 8-13.

66. Craveiro, A.A.; Queiroz, D.C. Óleos essenciais e química fina. Quím. Nova 1993, 16, 224-228.

67. Karlberg, A.T.; Dooms-Goossens, A. Contact allergy to oxidized d-limonene among dermatitis patients. Contact Derm. 1997, 36, 201-206.

68. Siani, A.C.; Sampaio, A.L.F.; Souza, M.C.; Henriques, M.; Ramos, M.F.S. Óleos essenciais: Potencial antiinflamatório. Biotecnol.: Ciênc. Desenvolv. 2000, 16, 38-43.

69. Maruzzella, J.C.; Liguori, L. The in vitro antifungal activity of essential oils. J. Am. Pharm. Assoc. 1958, 47, 250-254.

70. Toama, M.A.; El-Alfy, T.S.; El-Fatatry, H.M. Antimicrobial activity of the volatile oil of Nigella. sativa linneaus seeds. Antimicrob. Agents Chemother. 1974, 6, 225-226.

71. Banerjee, A.; Nigam, S.S. Antifungal activity of the essential oil of Curcuma caesia roxb. Indian J. Med. Res. 1976, 64, 1318-1321.

72. Nenoff, P.; Haustein, U.F.; Brandt, W. Antifungal activity of the essential oil of Melaleuca alternifolia (tea tree oil) against pathogenic fungi in vitro. Skin Pharmacol. 1996, 9, 388-394.

73. Mastura, M.; Azah, M.A.N.; Khozirah, S.; Mawardi, R.; Manaf, A.A. Anticandidal and antidermatophytic activity of Cinnamomum species essential oils. Cytobios 1999, 98, 17-23.

74. Viollon, C.; Chaumont, J.-P. Antifungal properties of essential oils and their main components upon Cryptococcus neoformans. Mycopathologia 1994, 128, 151-153.

75. Corrêa, M.P. Dicionário de Plantas úteis do Brasil e das Exóticas Cultivadas; Ministério da Agricultura, Instituto Brasileiro de Desenvolvimento Florestal: Rio de Janeiro, Brasil, 1984.

76. Cortez, D.A.G.; Cortez, L.E.R., Pessini, G.L.; Doro, D.L.; Nakamura, C.V. Analysis of essential oil of alfavaca Ocimum. gratissimum L. (labiatae). Arq. Ciênc. Saúde UNIPAR 1998, 2, 125-127.

77. De Oliveira Lima, I.; Oliveira, R.D.A.G.; de Oliveira Lima, E.; Farias, N.M.P.; de Souza, E.L. Atividade antifúngica de óleos essenciais sobre espécies de Candida. Rev. Bras. Farmacogn. 2006, 16, 197-201.

78. Ribeiro, D.I.; Alves, M.D.S.; Faria, M.G.I.; Svidzinski, T.I.E.; Nascimento, I.A.; Ferreira, F.B.P.; Ferreira, G.A.; Gazim, Z.C. Determination of antifungal activity of essential oils of Curcuma longa L. (Zingiberaceae) and Achillea. millefolium (Asteraceae) grown in the northwest Paraná. Arq. Ciênc. Saúde UNIPAR 2010, 14, 103-109.

79. Bajpai, V.K.; Yoon, J.I.; Kang, S.C. Antifungal potential of essential oil and various organic extracts of Nandina domestica thunb. against skin infectious fungal pathogens. Appl. Microbiol. Biotechnol. 2009, 83, 1127-1133. 
80. Pandey, A.K.; Mishra, A.K.; Mishra, A. Antifungal and antioxidative potential of oil and extracts derived from leaves of indian spice plant Cinnamomum tamala. Cell. Mol. Biol. 2012, 58, 142-147.

81. Carmo, E.S.; Pereira, F.d.O.; Cavalcante, N.M.; Gayoso, C.W.; Lima, E.O. Treatment of pityriasis versicolor with topical application of essential oil of Cymbopogon citratus (DC) stapf-therapeutic pilot study. An. Bras. Dermatol. 2013, 88, 381-385.

82. Bouzabata, A.; Bazzali, O.; Cabral, C.; Gonçalves, M.J.; Teresa Cruz, M.; Bighelli, A.; Cavaleiro, C.; Casanova, J.; Salgueiro, L.; Tomi, F. New compounds, chemical composition, antifungal activity and cytotoxicity of the essential oil from Myrtus nivellei batt. \& trab., an endemic species of central sahara. J. Ethnopharmacol. 2013, 149, 613-620.

83. Sookto, T.; Srithavaj, T.; Thaweboon, S.; Thaweboon, B.; Shrestha, B.; Nakazawa, F. In vitro effects of Salvia officinalis L. essential oil on Candida albicans. Asian Pac. J. Trop. Biomed. 2013, 3, 376-380.

84. Souza, E.L.D.; Lima, E.D.O.; Freire, K.R.D.L.; Sousa, C.P.D. Inhibitory action of some essential oils and phytochemicals on the growth of various moulds isolated from foods. Braz. Arch. Biol. Technol. 2005, 48, 245-250.

85. Flach, A.; Gregel, B.; Simionatto, E.; da Silva, U.F.; Zanatta, N.; Morel, A.F.; Linares, C.E.B.; Alves, S.H. Chemical analysis and antifungal activity of the essential oil of Calea. clematidea. Planta Med. 2002, 68, 836-838.

86. Pinto, E.; Salgueiro, L.R.; Cavaleiro, C.; Palmeira, A.; Gonçalves, M.J. In vitro susceptibility of some species of yeasts and filamentous fungi to essential oils of Salvia officinalis. Ind. Crop. Prod. 2007, 26, 135-141.

87. Gazim, Z.C.; Rezende, C.M.; Fraga, S.R.; Svidzinski, T.I.E.; Cortez, D.A.G. Antifungal activity of the essential oil from Calendula officinalis L. (Asteraceae) growing in Brazil. Braz. J. Microbiol. 2008, 39, 61-63.

88. Silva, D.R.; Endo, E.H.; Nakamura, C.V.; Svidzinski, T.I.E.; de Souza, A.; Young, M.C.M.; Ueda-Nakamura, T.; Cortez, D.A.G. Chemical composition and antimicrobial properties of Piper ovatum Vahl. Molecules 2009, 14, 1171-1182.

89. Nakamura, C.V.; de Paulo, L.F.; Young, M.C.M.; Svidzinski, T.I.E.I.E., Chemical composition and antifungal activity of the essential oil from Piper amalago L. Lat. Am. J. Pharm. 2010, 29, 1459-1462.

90. Taweechaisupapong, S.; Singhara, S.; Lertsatitthanakorn, P.; Khunkitti, W. Antimicrobial effects of Boesenbergia. pandurata and Piper sarmentosum leaf extracts on planktonic cells and biofilm of oral pathogens. Pak. J. Pharm. Sci. 2010, 23, 224-231.

91. Silva, F.; Ferreira, S.; Duarte, A.; Mendonça, D.I.; Domingues, F.C. Antifungal activity of Coriandrum sativum essential oil, its mode of action against Candida species and potential synergism with amphotericin B. Phytomedicine 2011, 19, 42-47.

92. Vieira, S.C.H.; Paulo, L.F.D.; Svidzinski, T.I.E.; Dias Filho, B.P.; Nakamura, C.V.; Souza, A.D.; Young, M.C.M.; Cortez, D.A.G. Antifungal activity of Piper diospyrifolium Kunth (Piperaceae) essential oil. Braz. J. Microbiol. 2011, 42, 1001-1006. 
93. Saharkhiz, M.J.; Motamedi, M.; Zomorodian, K.; Pakshir, K.; Miri, R.; Hemyari, K. Chemical composition, antifungal and antibiofilm activities of the essential oil of Mentha piperita L. ISRN Pharm. 2012, 2012, 1-6.

94. Mello, J.C.P.D.; Mentz, L.A.; Petrovick, P.R. Farmacognosia: Da Planta ao Medicamento; Porto Alegre, EFRGS: Porto Alegre, Brazil, 2003.

95. Barchiesi, F.; Silvestri, C.; Arzeni, D.; Ganzetti, G.; Castelletti, S.; Simonetti, O.; Cirioni, O.; Kamysz, W.; Kamysz, E.; Spreghini, E. In vitro susceptibility of dermatophytes to conventional and alternative antifungal agents. Med. Mycol. 2008, 47, 321-326.

96. Hammer, K.A.; Carson, C.F.; Riley, T.V. Melaleuca alternifolia (tea tree) oil inhibits germ tube formation by Candida albicans. Med. Mycol. 2000, 38, 354-361.

97. Palmeira-de-Oliveira, A.; Salgueiro, L.; Palmeira-de-Oliveira, R.; Martinez-de-Oliveira, J.; Pina-Vaz, C.; Queiroz, J.A.; Rodrigues, A.G. Anti-candida activity of essential oils. Mini. Rev. Med. Chem. 2009, 9, 1292-1305.

98. Pauli, A. Anticandidal low molecular compounds from higher plants with special reference to compounds from essential oils. Med. Res. Rev. 2006, 26, 223-268.

99. Marcos-Arias, C.; Eraso, E.; Madariaga, L.; Quindós, G. In vitro activities of natural products against oral Candida isolates from denture wearers. BMC Complement. Altern. Med. 2011, 11, 119-126.

100. Machumi, F.; Samoylenko, V.; Yenesew, A.; Derese, S.; Midiwo, J.O.; Wiggers, F.T.; Jacob, M.R.; Tekwani, B.L.; Khan, S.I.; Walker, L.A. Antimicrobial and antiparasitic abietane diterpenoids from the roots of Clerodendrum. eriophyllum. Nat. Prod. Commun. 2010, 5, 853-858.

101. Amber, K.; Aijaz, A.; Immaculata, X.; Luqman, K.A.; Nikhat, M. Anticandidal effect of Ocimum sanctum essential oil and its synergy with fluconazole and ketoconazole. Phytomedicine 2010, 17, 921-925.

102. Burdock, G.A. Review of the biological properties and toxicity of bee propolis (propolis). Food Chem. Toxicol. 1998, 36, 347-363.

103. Bankova, V.S.; de Castro, S.L.; Marcucci, M.C. Propolis: Recent advances in chemistry and plant origin. Apidologie 2000, 31, 3-16.

104. Teixeira, E.W.; Negri, G.; Salatino, A.; Stringheta, P.C. Seasonal variation, chemical composition and antioxidant activity of Brazilian propolis samples. Evid. Based Complement. Alternat. Med. 2010, 7, 307-315.

105. Monzote, L.; Cuesta-Rubio, O.; Campo Fernandez, M.; Márquez Hernandez, I.; Fraga, J.; Pérez, K.; Kerstens, M.; Maes, L.; Cos, P. In vitro antimicrobial assessment of Cuban propolis extracts. Mem. Inst. Oswaldo Cruz 2012, 107, 978-984.

106. Bonvehí, J.S.; Gutiérrez, A.L. The antimicrobial effects of propolis collected in different regions in the Basque country (northern Spain). World J. Microbiol. Biotechnol. 2012, 28, 1351-1358.

107. Kujumgiev, A.; Tsvetkova, I.; Serkedjieva, Y.; Bankova, V.; Christov, R.; Popov, S. Antibacterial, antifungal and antiviral activity of propolis of different geographic origin. J. Ethnopharmacol. 1999, 64, 235-240.

108. Ota, C.; Unterkircher, C.; Fantinato, V.; Shimizu, M.T. Antifungal activity of propolis on different species of Candida. Mycoses 2001, 44, 375-378. 
109. Dalben-Dota, K.F.; Faria, M.G.I.; Bruschi, M.L.; Pelloso, S.M.; Lopes-Consolaro, M.E.; Svidzinski, T.I.E.I.E., Antifungal activity of propolis extract against yeasts isolated from vaginal exudates. J. Altern. Complement. Med. 2010, 16, 285-290.

110. Oliveira, A.C.P.; Shinobu, C.S.; Longhini, R.; Franco, S.L.; Svidzinski, T.I.E.I.E., Antifungal activity of propolis extract against yeasts isolated from onychomycosis lesions. Mem. Inst. Oswaldo Cruz 2006, 101, 493-497.

111. Fernandes, F.F.; Dias, A.L.T.; Ramos, C.L.; Ikegaki, M.; Siqueira, A.M.D.; Franco, M.C. The "in vitro" antifungal activity evaluation of propolis g12 ethanol extract on Cryptococcus neoformans. Rev. Inst. Med. Trop. São Paulo 2007, 49, 93-95.

112. Murad, J.M.; Calvi, S.A.; Soares, A.; Bankova, V.; Sforcin, J.M. Effects of propolis from Brazil and Bulgaria on fungicidal activity of macrophages against Paracoccidioides brasiliensis. J. Ethnopharmacol. 2002, 79, 331-334.

113. Avanço, G.B.; Bruschi, M.L. Preparation and characterisation of ethylcellulose microparticles containing propolis. Rev. Ciênc. Farm. Básica Apl. 2009, 29, 129-135.

114. Dota, K.F.D.; Consolaro, M.E.L.; Svidzinski, T.I.E.; Bruschi, M.L. Antifungal activity of Brazilian propolis microparticles against yeasts isolated from vulvovaginal candidiasis. Evid. Based Complement. Alternat. Med. 2011, 2011, 201953.

115. Harris, J.C.; Cottrell, S.; Plummer, S.; Lloyd, D. Antimicrobial properties of Allium sativum (garlic). Appl. Microbiol. Biotechnol. 2001, 57, 282-286.

116. Block, E. The organosulfur chemistry of the genus allium-implications for the organic chemistry of sulfur. Angewandte. Chemie. Angew. Chem. Int. Ed. Engl. 1992, 31, 1135-1178.

117. Yoshida, H.; Iwata, N.; Katsuzaki, H.; Naganawa, R.; Ishikawa, K.; Fukuda, H.; Fujino, T.; Suzuki, A. Antimicrobial activity of a compound isolated from an oil-macerated garlic extract. Biosci. Biotechnol. Biochem. 1998, 62, 1014-1017.

118. Rev, N. Efectos del ajoeno sobre dermatofitos, Candida albicans y Malassezia furfur. Rev. Iberoam. Micol. 1998, 15, 277-281.

119. Ledezma, E.; Apitz-Castro, R. Ajoene the main active compound of garlic (Allium sativum): A new antifungal agent. Rev. Iberoam. Micol. 2006, 23, 75-80.

120. Yoshida, S.; Kasuga, S.; Hayashi, N.; Ushiroguchi, T.; Matsuura, H.; Nakagawa, S. Antifungal activity of ajoene derived from garlic. Appl. Environ. Microbiol. 1987, 53, 615-617.

121. Davis, S.R.; Perrie, R.; Apitz-Castro, R. The in vitro susceptibility of Scedosporium prolificans to ajoene, allitridium and a raw extract of garlic (Allium sativum). J. Antimicrob. Chemother. 2003, 51, 593-597.

122. San-Blas, G.; San-Blas, F.; Gil, F.; Marino, L.; Apitz-Castro, R. Inhibition of growth of the dimorphic fungus Paracoccidioides brasiliensis by ajoene. Antimicrob. Agents Chemother. 1989, $33,1641-1644$.

123. Visbal, G.; San-Blas, G.; Murgich, J.; Franco, H. Paracoccidioides brasiliensis, paracoccidioidomycosis, and antifungal antibiotics. Curr. Drug Targets Infect. Disord. 2005, 5, 211-226.

124. Alastruey-Izquierdo, A.; Cuenca-Estrella, M.; Monzón, A.; Mellado, E.; Rodríguez-Tudela, J.L. Antifungal susceptibility profile of clinical Fusarium spp. isolates identified by molecular methods. J. Antimicrob. Chemother. 2008, 61, 805-809. 
125. Lalitha, P.; Shapiro, B.L.; Srinivasan, M.; Prajna, N.V.; Acharya, N.R.; Fothergill, A.W.; Ruiz, J.; Chidambaram, J.D.; Maxey, K.J.; Hong, K.C. Antimicrobial susceptibility of Fusarium, Aspergillus, and other filamentous fungi isolated from keratitis. Arch. Ophthalmol. 2007, 125, 789-793.

126. Lewis, R.E.; Wiederhold, N.P.; Klepser, M.E. In vitro pharmacodynamics of amphotericin B, itraconazole, and voriconazole against Aspergillus, Fusarium, and Scedosporium spp. Antimicrob. Agents Chemother. 2005, 49, 945-951.

127. San-Blas, G.; Marino, L.; San-Blas, F.; Apitz-Castro, R. Effect of ajoene on dimorphism of Paracoccidioides brasiliensis. Med. Mycol. 1993, 31, 133-141.

128. Maluf, M.L.; Takahachi, G.; Svidzinski, T.I.; Xander, P.; Apitz-Castro, R.; Bersani-Amado, C.A.; Cuman, R.K.N. Antifungal activity of ajoene on experimental murine paracoccidioidomycosis. Rev. Iberoam. Micol. 2008, 25, 163-166.

129. Ledezma, E.; Marcano, K.; Jorquera, A.; de Sousa, L.; Padilla, M.; Pulgar, M.; Apitz-Castro, R. Efficacy of ajoene in the treatment of tinea pedis: A double-blind and comparative study with terbinafine. J. Am. Acad. Dermatol. 2000, 43, 829-832.

130. Ledezma, E.; Sousa, L.D.; Jorquera, A.; Sanchez, J.; Lander, A.; Rodriguez, E.; Jain, M.K.; Apitz-Castro, R. Efficacy of ajoene, an organosulphur derived from garlic, in the short-term therapy of tinea pedis. Mycoses 1996, 39, 393-395.

131. Ledezma, E.; López, J.C.; Marin, P.; Romero, H.; Ferrara, G.; de Sousa, L.; Jorquera, A.; Castro, R.A. Ajoene in the topical short-term treatment of tinea cruris and tinea corporis in humans. Arzneimittelforschung 1999, 49, 544-547.

132. Pérez-Blanco, M.; Hernández Valles, R.; Fernández Zeppenfeldt, G.; Apitz-Castro, R. Ajoene and 5-fluorouracil in the topical treatment of Cladophialophora carrionii chromoblastomycosis in humans: A comparative open study. Med. Mycol. 2003, 41, 517-520.

133. Marston, A.; Hostettmann, K. Review article number 6: Plant molluscicides. Phytochemistry 1985, 24, 639-652.

134. Connolly, J.D.; Hill, R.A. Triterpenoids. Nat. Prod. Rep. 2005, 22, 230-248.

135. Phillips, D.R.; Rasbery, J.M.; Bartel, B.; Matsuda, S. Biosynthetic diversity in plant triterpene cyclization. Curr. Opin. Plant. Biol. 2006, 9, 305-314.

136. Vincken, J.-P.; Heng, L.; de Groot, A.; Gruppen, H. Saponins, classification and occurrence in the plant kingdom. Phytochemistry 2007, 68, 275-297.

137. Yendo, A.C.A.; de Costa, F.; Gosmann, G.; Fett-Neto, A.G. Production of plant bioactive triterpenoid saponins: Elicitation strategies and target genes to improve yields. Mol. Biotechnol. 2010, 46, 94-104.

138. Osbourn, A.E. Saponins in cereals. Phytochemistry 2003, 62, 1-4.

139. Dini, I.; Tenore, G.C.; Schettino, O.; Dini, A. New oleanane saponins in Chenopodium. quinoa. J. Agric. Food Chem. 2001, 49, 3976-3981.

140. Dini, I.; Schettino, O.; Simioli, T.; Dini, A. Studies on the constituents of Chenopodium quinoa seeds: Isolation and characterization of new triterpene saponins. J. Agric. Food Chem. 2001, 49, 741-746.

141. Sparg, S.G.; Light, M.E.; van Staden, J. Biological activities and distribution of plant saponins. J. Ethnopharmacol. 2004, 94, 219-243. 
142. Escalante, A.M.; Santecchia, C.B.; López, S.N.; Gattuso, M.A.; Gutiérrez Ravelo, A.; Delle Monache, F.; Gonzalez Sierra, M.; Zacchino, S.A. Isolation of antifungal saponins from Phytolacca tetramera, an Argentinean species in critic risk. J. Ethnopharmacol. 2002, 82, 29-34.

143. Liberto, M.D.; Svetaz, L.; Furlán, R.L.E.; Zacchino, S.A.; Delporte, C.; Novoa, M.A.; Asencio, M.; Cassels, B.K. Antifungal activity of saponin-rich extracts of Phytolacca dioica and of the sapogenins obtained through hydrolysis. Nat. Prod. Commun. 2010, 5, 1013-1018.

144. Houghton, P.; Patel, N.; Jurzysta, M.; Biely, Z.; Cheung, C. Antidermatophyte activity of medicago extracts and contained saponins and their structure-activity relationships. Phytother. Res. 2006, 20, 1061-1066.

145. Zhang, J.D.; Cao, Y.B.; Xu, Z.; Sun, H.H.; An, M.M.; Yan, L.; Chen, H.S.; Gao, P.H.; Wang, Y.; Jia, X.M. In vitro and in vivo antifungal activities of the eight steroid saponins from Tribulus terrestris L. with potent activity against fluconazole-resistant fungal. Biol. Pharm. Bull. 2005, 28, 2211-2215.

146. Zhang, J.D.; Xu, Z.; Cao, Y.B.; Chen, H.S.; Yan, L.; An, M.M.; Gao, P.H.; Wang, Y.; Jia, X.M.; Jiang, Y.Y. Antifungal activities and action mechanisms of compounds from Tribulus terrestris L. J. Ethnopharmacol. 2006, 103, 76-84.

147. Coleman, J.J.; Okoli, I.; Tegos, G.P.; Holson, E.B.; Wagner, F.F.; Hamblin, M.R.; Mylonakis, E. Characterization of plant-derived saponin natural products against Candida albicans. ACS Chem. Biol. 2010, 5, 321-332.

148. Tsuzuki, J.K.; Svidzinski, T.I.E.; Shinobu, C.S.; Silva, L.F.A.; Rodrigues-Filho, E.; Cortez, D.A.G.; Ferreira, I.C.P. Antifungal activity of the extracts and saponins from Sapindus saponaria L. Anais Acad. Bras. Ciênc. 2007, 79, 577-583.

149. Damke, E.; Tsuzuki, J.K.; Cortez, D.A.; Ferreira, I.C.; Bertoni, T.A.; Batista, M.R.; Donati, L.; Svidzinski, T.I.; Consolaro, M.E. In vivo activity of Sapindus saponaria against azole-susceptible and -resistant human vaginal Candida species. BMC Complement. Altern. Med. 2011, 11, 35 .

150. Evans, W.C. Trease and Evans' Pharmacognosy; Elsevier Health Sciences: New York, NY, USA, 2009.

151. Mollataghi, A.; Coudiere, E.; Hadi, A.H.A.; Mukhtar, M.R.; Awang, K.; Litaudon, M.; Ata, A. Anti-acetylcholinesterase, anti- $\alpha$-glucosidase, anti-leishmanial and anti-fungal activities of chemical constituents of Beilschmiedia species. Fitoterapia 2012, 83, 298-302.

152. Meng, F.; Zuo, G.; Hao, X.; Wang, G.; Xiao, H.; Zhang, J.; Xu, G. Antifungal activity of the benzo $[c]$ phenanthridine alkaloids from Chelidonium. majus Linn against resistant clinical yeast isolates. J. Ethnopharmacol. 2009, 125, 494-496.

153. Rankovič, B.; Rankovic, D.; Maric, D. Antioxidant and antimicrobial activity of some Lichen species. Microbiology 2010, 79, 809-815.

154. Ayala-Zavala, J.F.; Silva-Espinoza, B.A.; Cruz-Valenzuela, M.R.; Villegas-Ochoa, M.A.; Esqueda, M.; González-Aguilar, G.A.; Calderón-López, Y. Antioxidant and antifungal potential of methanol extracts of Phellinus spp. from sonora, mexico. Rev. Iberoam. Micol. 2012, 29, $132-138$.

155. Vijayarathna, S.; Zakaria, Z.; Chen, Y.; Latha, L.Y.; Kanwar, J.R.; Sasidharan, S. The antimicrobial efficacy of Elaeis guineensis: Characterization, in vitro and in vivo studies. Molecules 2012, 17, 4860-4877. 
156. Kumar, R.S.; Sivakumar, T.; Sunderam, R.S.; Gupta, M.; Mazumdar, U.K.; Gomathi, P.; Rajeshwar, Y.; Saravanan, S.; Kumar, M.S.; Murugesh, K. Antioxidant and antimicrobial activities of Bauhinia racemosa L. Stem bark. Braz. J. Med. Biol. Res. 2005, 38, 1015-1024.

157. Chaieb, K.; Zmantar, T.; Ksouri, R.; Hajlaoui, H.; Mahdouani, K.; Abdelly, C.; Bakhrouf, A. Antioxidant properties of the essential oil of Eugenia caryophyllata and its antifungal activity against a large number of clinical Candida species. Mycoses 2007, 50, 403-406.

158. ElSohly, H.N.; Joshi, A.S.; Nimrod, A.C.; Walker, L.A.; Clark, A.M. Antifungal chalcones from Maclura. tinctoria. Planta Med. 2001, 67, 87-89.

159. Sathiamoorthy, B.; Gupta, P.; Kumar, M.; Chaturvedi, A.K.; Shukla, P.K.; Maurya, R. New antifungal flavonoid glycoside from Vitex. negundo. Bioorg. Med. Chem. Lett. 2007, 17, 239-242.

160. Martins, C.V.B.; da Silva, D.L.; Neres, A.T.M.; Magalhaes, T.F.F.; Watanabe, G.A.; Modolo, L.V.; Sabino, A.A.; de Fátima, A.; de Resende, M.A. Curcumin as a promising antifungal of clinical interest. J. Antimicrob. Chemother. 2009, 63, 337-339.

161. Mbaveng, A.T.; Kuete, V.; Ngameni, B.; Beng, V.P.; Ngadjui, B.T.; Meyer, J.J.M.; Lall, N. Antimicrobial activities of the methanol extract and compounds from the twigs of Dorstenia mannii (Moraceae). BMC Complement. Alter. Med. 2012, 12, 83-88.

162. Sanguinetti, M.; Posteraro, B.; Romano, L.; Battaglia, F.; Lopizzo, T.; de Carolis, E.; Fadda, G. In vitro activity of Citrus bergamia (Bergamot) oil against clinical isolates of dermatophytes. J. Antimicrob. Chemother. 2007, 59, 305-308.

163. Verzera, A.; Trozzi, A.; Gazea, F.; Cicciarello, G.; Cotroneo, A. Effects of rootstock on the composition of bergamot (Citrus bergamia risso et poiteau) essential oil. J. Agric. Food Chem. 2003, 51, 206-210.

164. Romano, L.; Battaglia, F.; Masucci, L.; Sanguinetti, M.; Posteraro, B.; Plotti, G.; Zanetti, S.; Fadda, G. In vitro activity of bergamot natural essence and furocoumarin-free and distilled extracts, and their associations with boric acid, against clinical yeast isolates. J. Antimicrob. Chemother. 2005, 55, 110-114.

165. Fotie, J.; Bohle, D.S. Pharmacological and biological activities of xanthones. Antiinfect. Agents Med. Chem. 2006, 5, 15-31.

166. Sousa, M.E.; Pinto, M.M.M. Synthesis of xanthones: An overview. Curr. Med. Chem. 2005, 12, 2447-2479.

167. Na, Y. Recent cancer drug development with xanthone structures. J. Pharm. Pharmacol. 2009, 61, 707-712.

168. Pinto, D.C.G.; Fuzzati, N.; Pazmino, X.C.; Hostettmann, K. Xanthone and antifungal constituents from Monnina obtusifolia. Phytochemistry 1994, 37, 875-878.

169. Pinto, E.; Afonso, C.; Duarte, S.; Vale-Silva, L.; Costa, E.; Sousa, E.; Pinto, M. Antifungal activity of xanthones: Evaluation of their effect on ergosterol biosynthesis by high-performance liquid chromatography. Chem. Biol. Drug Des. 2011, 77, 212-222.

170. Tocci, N.; D’Auria, F.D.; Simonetti, G.; Panella, S.; Palamara, A.T.; Debrassi, A.; Clovis, A.R.; Cechinel Filho, V.; Sciubba, F.; Pasqua, G. Bioassay-guided fractionation of extracts from Hypericum perforatum in vitro roots treated with carboxymethylchitosans and determination of antifungal activity against human fungal pathogens. Plant Physiol. Biochem. 2013, 70, 342-347. 
171. Peterson, J.; Dwyer, J.; Adlercreutz, H.; Scalbert, A.; Jacques, P.; McCullough, M.L. Dietary lignans: Physiology and potential for cardiovascular disease risk reduction. Nutr. Rev. 2010, 68, 571-603.

172. Kim, M.-R.; Moon, H.T.; Lee, D.G.; Woo, E.-R. A new lignan glycoside from the stem bark of Styrax japonica s. Et z. Arch. Pharm. Res. 2007, 30, 425-430.

173. Park, C.; Woo, E.-R.; Lee, D.G. Anti-candida property of a lignan glycoside derived from Styrax japonica s. Et z. via membrane-active mechanisms. Mol. Cells 2010, 29, 581-584.

174. Koroishi, A.M.; Foss, S.R.; Cortez, D.A.G.; Ueda-Nakamura, T.; Nakamura, C.V.; Dias Filho, B.P. In vitro antifungal activity of extracts and neolignans from Piper regnellii against dermatophytes. J. Ethnopharmacol. 2008, 117, 270-277.

175. Liu, M.; Katerere, D.R.; Gray, A.I.; Seidel, V. Phytochemical and antifungal studies on Terminalia. mollis and Terminalia brachystemma. Fitoterapia 2009, 80, 369-373.

176. Santos, C.A.D.M.; Torres, K.R.; Leonart, R. Plantas. Medicinais: Herbarium, Flora et Scientia; Medicinal Plants: Herbariun., Flora et Scientia; Scientia et labor: Curitiba, Brazil, 1988.

177. Alzugaray, D.; Alzugaray, C. Plantas Que Curam, 3rd ed.; M.V.P. Publisher: São Paulo, Brazil, 1983.

178. Ishida, K.; de Mello, J.C.P.; Cortez, D.A.G.; Dias Filho, B.P.; Ueda-Nakamura, T.; Nakamura, C.V. Influence of tannins from Stryphnodendron adstringens on growth and virulence factors of Candida albicans. J. Antimicrob. Chemother. 2006, 58, 942-949.

179. Ishida, K.; Rozental, S.; de Mello, J.C.P.; Nakamura, C.V. Activity of tannins from Stryphnodendron adstringens on Cryptococcus neoformans: Effects on growth, capsule size and pigmentation. Ann. Clin. Microbiol. Antimicrob. 2009, 8, 29-38.

180. Berdy, J. Bioactive microbial metabolites. J. Antibiot. 2005, 58, 1-26.

181. Demain, A.L.; Sanchez, S. Microbial drug discovery: 80 years of progress. J. Antibiot. 2009, 62, 5-16.

182. Phongpaichit, S.; Rungjindamai, N.; Rukachaisirikul, V.; Sakayaroj, J. Antimicrobial activity in cultures of endophytic fungi isolated from Garcinia species. FEMS Immunol. Med. Microbiol. 2006, 48, 367-372.

183. Gao, X.; Lu, Y.; Xing, Y.; Ma, Y.; Lu, J.; Bao, W.; Wang, Y.; Xi, T. A novel anticancer and antifungus phenazine derivative from a marine actinomycete bm-17. Microbiol. Res. 2012, 167, $616-622$.

184. Xu, L.L.; Han, T.; Wu, J.Z.; Zhang, Q.Y.; Zhang, H.; Huang, B.K.; Rahman, K.; Qin, L.P. Comparative research of chemical constituents, antifungal and antitumor properties of ether extracts of Panax ginseng and its endophytic fungus. Phytomedicine 2009, 16, 609-616.

185. Hertzberg, R.P.; Pope, A.J. High-throughput screening: New technology for the 21 st century. Curr. Opin. Chem. Boil. 2000, 4, 445-451.

186. Congreve, M.; Murray, C.W.; Blundell, T.L. Keynote review: Structural biology and drug discovery. Drug Discov. Today 2005, 10, 895-907.

187. Kitamura, A.; Someya, K.; Hata, M.; Nakajima, R.; Takemura, M. Discovery of a smallmolecule inhibitor of $\beta$-1,6-glucan synthesis. Antimicrob. Agents Chemother. 2009, 53, 670-677.

188. Kitamura, A.; Someya, K.; Okumura, R.; Hata, M.; Takeshita, H.; Nakajima, R. In vitro antifungal activities of D11-2040, a beta-1,6-glucan inhibitor, with or without currently available antifungal drugs. Biol. Pharm. Bull. 2010, 33, 192-197. 
189. Bauer, J.R.; Kinast, S.; Burger-Kentischer, A.; Finkelmeier, D.; Kleymann, G.; Rayyan, W.A.; Schröppel, K.; Singh, A.; Jung, G.N.; Wiesmüller, K.H. High-throughput-screening-based identification and structure-activity relationship characterization defined (S)-2-(1-aminoisobutyl)-1(3-chlorobenzyl) benzimidazole as a highly antimycotic agent nontoxic to cell lines. J. Med. Chem. 2011, 54, 6993-6997.

190. Burger-Kentischer, A.; Finkelmeier, D.; Keller, P.; Bauer, J.; Eickhoff, H.; Kleymann, G.; Rayyan, W.A.; Singh, A.; Schröppel, K.; Lemuth, K. A screening assay based on host-pathogen interaction models identifies a set of novel antifungal benzimidazole derivatives. Antimicrob. Agents Chemother. 2011, 55, 4789-4801.

191. Chaturvedi, S.; Rajkumar, S.S.; Li, X.; Hurteau, G.J.; Shtutman, M.; Chaturvedi, V. Antifungal testing and high-throughput screening of compound library against Geomyces destructans, the etiologic agent of geomycosis (wns) in bats. PLoS One 2011, 6, e17032.

192. Sun, W.; Park, Y.D.; Sugui, J.A.; Fothergill, A.; Southall, N.; Shinn, P.; McKew, J.C.; Kwon-Chung, K.J.; Zheng, W.; Williamson, P.R. Rapid identification of antifungal compounds against exserohilum rostratum using high throughput drug repurposing screens. PloS One 2013, 8, e70506.

193. Macarron, R.; Banks, M.N.; Bojanic, D.; Burns, D.J.; Cirovic, D.A.; Garyantes, T.; Green, D.V.S.; Hertzberg, R.P.; Janzen, W.P.; Paslay, J.W. Impact of high-throughput screening in biomedical research. Nat. Rev. Drug Discov. 2011, 10, 188-195.

194. Sukumar, N.; Krein, M.P.; Embrechts, M.J. Predictive cheminformatics in drug discovery: Statistical modeling for analysis of micro-array and gene expression data. In Bioinformatics and Drug Discovery; Larson, R.S., Ed.; Springer: New York, NY, USA, 2012; Volume 910, pp. 165-194.

195. Bredel, M.; Jacoby, E. Chemogenomics: An emerging strategy for rapid target and drug discovery. Nat. Rev. Genet. 2004, 5, 262-275.

196. Bleicher, K.H.; Böhm, H.J.; Müller, K.; Alanine, A.I. Hit and lead generation: Beyond high-throughput screening. Nat. Rev. Drug Discov. 2003, 2, 369-378.

197. Stumpfe, D.; Ripphausen, P.; Bajorath, J. Virtual compound screening in drug discovery. Future Med. Chem. 2012, 4, 593-602.

198. Basak, S.C. Chemobioinformatics: The advancing frontier of computer-aided drug design in the post-genomic era. Curr. Comput. Aided. Drug Des. 2012, 8, 1-2.

199. Abadio, A.K.R.; Kioshima, E.S.; Teixeira, M.M.; Martins, N.F.; Maigret, B.; Felipe, M.S.S. Comparative genomics allowed the identification of drug targets against human fungal pathogens. BMC Genomics 2011, 12, doi:10.1186/1471-2164-12-75.

200. Pierce, C.G.; Lopez-Ribot, J.L. Candidiasis drug discovery and development: New approaches targeting virulence for discovering and identifying new drugs. Expert Opin. Drug Discov. 2013, $8,1-10$.

201. Pierri, C.L.; Parisi, G.; Porcelli, V. Computational approaches for protein function prediction: A combined strategy from multiple sequence alignment to molecular docking-based virtual screening. Biochim. Biophys. Acta 2010, 1804, 1695-1712.

202. Cavasotto, C.N.; Phatak, S.S. Homology modeling in drug discovery: Current trends and applications. Drug Discov. Today 2009, 14, 676-683. 
203. Swinney, D.C.; Anthony, J. How were new medicines discovered? Nat. Rev. Drug Discov. 2011, 10, 507-519.

204. Berne, S.; Podobnik, B.; Zupanec, N.; Novak, M.; Kraševec, N.; Turk, S.; Korošec, B.; Lah, L.; Šuligoj, E.; Stojan, J. Virtual screening yields inhibitors of novel antifungal drug target, benzoate 4-monooxygenase. J. Chem. Inf. Model. 2012, 52, 3053-3063.

205. Morya, V.K.; Kumari, S.; Kim, E.K. Virtual screening and evaluation of ketol-acid reducto-isomerase (kari) as a putative drug target for aspergillosis. Clin. Proteomics 2012, 9, 1-12.

206. Sheng, C.; Wang, W.; Che, X.; Dong, G.; Wang, S.; Ji, H.; Miao, Z.; Yao, J.; Zhang, W. Improved model of lanosterol 14alpha-demethylase by ligand-supported homology modeling: Validation by virtual screening and azole optimization. Chem. Med. Chem. 2010, 5, 390-397.

207. Sheng, C.; Che, X.; Wang, W.; Wang, S.; Cao, Y.; Miao, Z.; Yao, J.; Zhang, W. Design and synthesis of novel triazole antifungal derivatives by structure-based bioisosterism. Eur. J. Med. Chem. 2011, 46, 5276-5282.

208. Zou, Y.; Zhao, Q.; Liao, J.; Hu, H.; Yu, S.; Chai, X.; Xu, M.; Wu, Q. New triazole derivatives as antifungal agents: Synthesis via click reaction, in vitro evaluation and molecular docking studies. Bioorg. Med. Chem. Lett. 2012, 22, 2959-2962.

209. Xu, J.; Cao, Y.; Zhang, J.; Yu, S.; Zou, Y.; Chai, X.; Wu, Q.; Zhang, D.; Jiang, Y.; Sun, Q. Design, synthesis and antifungal activities of novel 1, 2, 4-triazole derivatives. Eur. J. Med. Chem. 2011, 46, 3142-3148.

210. Chai, X.; Yang, G.; Zhang, J.; Yu, S.; Zou, Y.; Wu, Q.; Zhang, D.; Jiang, Y.; Cao, Y.; Sun, Q. Synthesis and biological evaluation of triazole derivatives as potential antifungal agent. Chem. Biol. Drug. Des. 2012, 80, 382-387.

211. Hata, M.; Ishii, Y.; Watanabe, E.; Uoto, K.; Kobayashi, S.; Yoshida, K.-I.; Otani, T.; Ando, A. Inhibition of ergosterol synthesis by novel antifungal compounds targeting c-14 reductase. Med. Mycol. 2010, 48, 613-621.

212. Cadicamo, C.D.; Mortier, M.J.; Wolber, G.; Hell, M.; Heinrich, I.E.; Michel, D.; Semlin, L.; Berger, U.; Korting, H.C.; Höltje, H.; et al. Design, synthesis, inhibition studies, and molecular modeling of pepstatin analogues addressing different secreted aspartic proteinases of Candida albicans. Biochem. Pharmacol. 2013, 85, 881-887.

213. Amaral, A.C.; Felipe, M.S.S. Nanobiotechnology: An efficient approach to drug delivery of unstable biomolecules. Curr. Protein Pept. Sci. 2013, 14, 588-594.

214. Van de Ven, H.; Paulussen, C.; Feijens, P.B.; Matheeussen, A.; Rombaut, P.; Kayaert, P.; van den Mooter, G.; Weyenberg, W.; Cos, P.; Maes, L. Plga nanoparticles and nanosuspensions with amphotericin B: Potent in vitro and in vivo alternatives to fungizone and ambisome. J. Controlled Release 2012, 161, 795-803.

215. Amaral, A.C.; Bocca, A.L.; Ribeiro, A.M.; Nunes, J.; Peixoto, D.L.G.; Simioni, A.R.; Primo, F.L.; Lacava, Z.G.M.; Bentes, R.; Titze-de-Almeida, R. Amphotericin B in poly (lactic-co-glycolic acid) (plga) and dimercaptosuccinic acid (dmsa) nanoparticles against paracoccidioidomycosis. J. Antimicrob. Chemother. 2009, 63, 526-533.

(C) 2014 by the authors; licensee MDPI, Basel, Switzerland. This article is an open access article distributed under the terms and conditions of the Creative Commons Attribution license (http://creativecommons.org/licenses/by/3.0/). 